\title{
Recent Progress in Metal-Based Nanoparticles Mediated Photodynamic Therapy
}

\author{
Jingyao Sun ${ }^{1,2} \mathbb{1}^{\mathbb{D}}$, Semen Kormakov ${ }^{1}{ }^{(\mathbb{D})}$, Ying Liu ${ }^{3}$, Yao Huang ${ }^{1}$, Daming Wu ${ }^{1,3, *}$ \\ and Zhaogang Yang ${ }^{2, *}$ \\ 1 College of Mechanical and Electrical Engineering, Beijing University of Chemical Technology, Beijing 100029, \\ China; sunjingyao5566@sina.com (J.S.); s_kormakov@bk.ru (S.K.); hy06@163.com (Y.H.) \\ 2 Department of Chemical and Biomolecular Engineering, The Ohio State University, Columbus, \\ OH 43210, USA \\ 3 State Key Laboratory of Organic-Inorganic Composites, Beijing 100029, China; liuying@mail.buct.edu.cn \\ * Correspondence: wudaming@vip.163.com (D.W.); yang.1140@osu.edu (Z.Y.)
}

Received: 4 June 2018; Accepted: 6 July 2018; Published: 12 July 2018

\begin{abstract}
Photodynamic therapy (PDT) is able to non-invasively treat and diagnose various cancers and nonmalignant diseases by combining light, oxygen, and photosensitizers (PSs). However, the application of PDT is hindered by poor water solubility and limited light-penetration depth of the currently available photosensitizers (PSs). Water solubility of PSs is crucial for designing pharmaceutical formulation and administration routes. Wavelength of light source at visible range normally has therapeutic depth less than $1 \mathrm{~mm}$. In this review, focus is on the recent research progress of metal-based nanoparticles being applied in PDT. The potential toxicity of these nanoscales and future directions are further discussed.
\end{abstract}

Keywords: photodynamic therapy; metal-based nanoparticles; potential toxicity

\section{Introduction}

Photodynamic therapy (PDT) is a modern and rapidly developing method for the diagnosis and treatment of a wide range of diseases from cancer treatment to root canal treatment, and with an increasing popularity owing to its antibacterial effect [1-3]. PDT involves the joint action of chemotherapeutic and physical (laser radiation, radiation of LEDs and other sources) factors in the presence of oxygen. The method is based on selective accumulation of photosensitizer in the tumor tissue, which is capable of generating cytotoxic agents that cause the death of tumor cells under local exposure to light with a wavelength corresponding to its maximum absorption $[4,5]$. The sensitizer is injected into the body, most often intravenously, and accumulates in the tissues of the tumor. Then, affected by the pathological process, the tissues are irradiated with light. The absorption of light quanta photosensitizer molecules in the presence of oxygen leads to a photochemical reaction, which results in the formation of singlet oxygen, causing tumor cell necrosis. In the early stages of tumor development, its cells are fed and oxygen by diffusion, but as the tissue grows there is a need for blood supply. The walls of the newly formed vessels are not as strong as in healthy vessels, so it is necessary to use nanoparticles that can penetrate the walls of the newly formed vessels and accumulate in the tumor tissues.

PDT is also used for the treatment of infectious agents in addition to the use of chemotherapy as one of the new effective antimicrobial techniques [6,7]. The basis of such therapy are photosensitizers, which are specific substances characterized by selective sensitivity to certain wavelengths of the optical range [8]. Photosensitizers and light irradiation taken separately do not have a therapeutic effect on the affected tissue [9]. The most significant component having an influential impact on photodynamic 
therapy process is photosensitizer. Appropriate choice of the substance is a guarantee of success. Photosensitizers should be characterized by i.e., selectivity for tumor cells, formation of a long-lived triplet excited state in reaction, activation with wavelength appropriate for tissue, and high chemical purity. The most important of these are activation wavelength and period of photo-sensitivity [10].

Today there are more than 1000 known photosensitizers that have both natural and synthetic origin (chlorophyll, phycobilin, porphyrins and intermediate products of their synthesis, some antibiotics, quinine, Riboflavin and several other drugs). Such photosensitizers should have the following characteristics: chemical purity and uniformity of composition; lack of dark toxicity; high ability to accumulate in the target tissue; rapid elimination from the patient's body; high photochemical activity characterized by high quantum yield of singlet oxygen; absorption of light in the long-wave part of the spectrum $(600-800 \mathrm{~nm})$, in which biological tissues are most transparent, with a high coefficient of extinction [11-13].

The mechanism of action of PDT is that when the photosensitizer molecule absorbs a quantum of light, it goes to an excited triplet state and enters into photochemical reactions of two types. In the first type of reactions there is an interaction directly with the molecules of the biological substrate, which ultimately leads to the formation of free radicals. In the second type of reactions there takes place interaction of the excited photosensitizer with oxygen molecule to form singlet oxygen which is cytotoxic for living cells due to its property of strong oxidizer [14]. The use of PDT is not limited to oncology. This is due to the fact that most PS are able to accumulate not only in the tumor area, but also in areas with some other pathologies. These pathologies include hyperplasia, metaplasia, and inflammation. In recent years, PDT has been used to treat infectious diseases caused by bacterial and fungal infections [15]. Efficacy of PDT is also shown for the treatment and prevention of several cardiovascular diseases, and blood sterilization [16].

Currently, the technology of PDT is becoming increasingly used in modern medicine. However, there are many factors that require further study in this area. Many modern scientists are working on optimizing the mechanism of delivery of photosensitizers to target tissues, accelerating and improving the impact of active substances on the body, reducing toxicity and accelerating the withdrawal of drugs after the procedure. A separate area of research in this area is the use of metal-based nanoparticles.

The mechanism of photodynamic action is complex and not fully understood. It is known that singlet oxygen plays the main role in PDT, which is formed in the molecules of lipids and proteins of cell membranes and intracellular organelles when exposed to them by the quantum of light [17]. When the light absorption of the molecule PS also moving from the core to an excited state. The excited light molecules, or quantum emission of fluorescence, enter into photochemical reactions of Type I or II (as shown in Figure 1). In Type I, PS molecules interact directly with tumor tissue molecules, forming intermediate radical products that then react with oxygen, which leads to the formation of various highly active substances, primarily active forms of oxygen, entering into further redox reactions. In this case, peroxide radicals, superoxide anion, hydroxyl radical are formed, lipid peroxidation is activated, and cell membranes are damaged in violation of their functions. In a photodynamic reaction of Type I, the photosensitizer molecule is excited and passes from the ground state first to the singlet state and to the triplet excited state. In Type II, PS molecules react first with oxygen, converting it into a highly active singlet form. It interacts with proteins, nucleic acids, and lipids of cell membranes, causing their death by necrosis or apoptosis. 


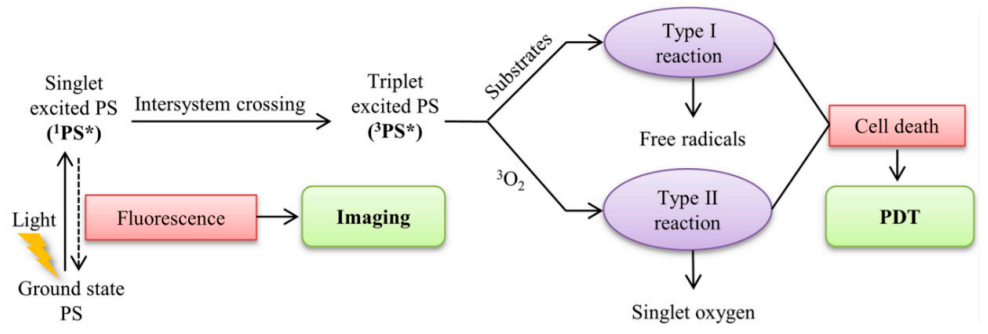

Figure 1. The schematic illustration of a typical photodynamic reaction (Reproduced with permission [18]).

However, not all possible reactions explaining the mechanism of PDT have been studied and understood. There are a number of contradictory experimental data. In Reference [19] a fundamentally different approach to PDT was proposed, based on the use of endogenous mechanisms for inducing photosensitivity. The idea was to create conditions in the body in which there would be an excessive amount of synthesis of endogenous porphyrins in tumor tissues. To this end, patients were orally administered d-aminolevulinic acid, which in itself is not PS and does not accumulate in cells, but a natural precursor of protoporphyrin IX. With exogenous administration of acid, protoporphyrin IX accumulates in tumor cells. Protoporphyrin IX is a sufficiently active PS with a maximum absorption at a wavelength of $630 \mathrm{~nm}$, capable of actively generating singlet oxygen. ALC-based PS has been successfully used for the diagnosis and treatment of keratosis, bladder cancer, and brain tumors. Thus, photodynamic reactions of Type I and II lead to the formation of high toxicity, the development of chain oxidation processes and, as a consequence, to the destruction of vital structures of cells and their death. These types of reactions can occur simultaneously. The advantage of this or that type of reaction is determined by the chemical structure of the photosensitizer, its concentration, the presence of extinguishers, as well as the ratio of the molecular oxygen content and the oxidized substrate in the tissues [20]. In the study of the distribution of PS in the body, it was noted that, in addition to the tissue of skin tumors, many of them are retained in high concentrations in the cells of the reticuloendothelial system, liver, kidneys, spleen, and inflamed tissues. This was a prerequisite for the study of the use of PDT in a new direction: for the treatment of diseases of non-tumor nature.

\section{Recent Progress of Photodynamic Therapy}

PDT is a method of local activation accumulated in the tissue fluorescent dye-photosensitizer by visible light in the presence of oxygen in the tissues, which leads to the development of free radical reactions and, ultimately, to the death of target cells. Assessing inequality in the distribution of such dyes in normal and pathological-modified tissue is based on fluorescent diagnostics [21,22]. Reactions underlying modern medical fields of PDT were used tens of centuries ago. The Egyptian papyri and ancient Indian medical literature describes the treatment of skin diseases, in particular vitiligo, with herbal preparations based on St. John's wort, caraway, parsley and parsnip. It is known that these plants contain photoactive compounds, derivatives of coumarins-psoralenes [23,24]. Isolated plant preparations were used internally or locally, and the subsequent insolation of pathological areas with bright sunlight contributed to the development of photosensitizing reactions $[25,26]$. The development of a modern approach to the study of photosensitizers and their impact on biological objects began with Reference [27], which described the death of Paramecia in an environment with small concentrations of dyes such as acridine, eosin, fluorescin, when exposed to sunlight, while in the dark cell death was not observed.

The first clinically approved photosensitizer, known as the "hematoporphyrin derivative" or $\mathrm{HpD}$, did not have a strictly defined chemical composition, but was a mixture of many porphyrins, including hematoporphyrin, protoporphyrin, deuteroporphyrin, their derivatives, monomers, dimers and oligomers and their esters. Photodynamic properties of hematoporphyrin, which became the basis for the first generation of clinical photosensitizers, were first discovered and published in 1911 in the 
work [28]. The first person who experienced the effect of hematoporphyrin on the human body was Meyer-Betz in 1912, when he injected himself with intravenous hematoporphyrin, resulting in swelling and pigmentation under the influence of sunlight were lasted for 2 months [29].

The ability of hematoporphyrin to selectively accumulate in the tumor was shown in Reference [30]. This work opened the possibility of using this compound for photodynamic therapy and fluorescence imaging of malignant neoplasms. Widespread PDT began in the second half of the 1970s, which is associated with the appearance of works [31,32]. These works reported the results of a successful application of a hematoporphyrin derivative in PDT for the treatment of patients with skin and basal cell carcinoma, melanoma metastases and breast cancer [33-35]. Currently, there is active research in the field of development of PDT. At the beginning of this century, new methods of diagnosis and treatment of tumors of the colon and bladder, tumors of the brain and spinal cord, new methods of treatment in skin and plastic surgery and cosmetology were developed [36-38]. To increase the efficiency of PDT, compounds were proposed with greater selectivity of accumulation in tumor tissue, better photosensitizing properties and providing an increase in the depth of photodynamic action by shifting the absorption maxima into a longer-wave region of the spectrum (more than $650 \mathrm{~nm}$ ) compared to first-generation drugs. Due to the individual characteristics of the patient's body, and considering the conditions of the disease, therapy requires the selection of optimal drugs for treatment. In this regard, a large amount of scientific work aims to study the most common and effective photosensitizers [39]. Ideally, this drug should meet the following requirements: to reliably generate a photodynamic reaction, to be hydrophilic for easy systemic application and nontoxic to activated light, to clinically activate beneficial light wavelengths. The drug should be well distributed on target tissues and leave the body quickly and completely after the procedure [40,41].

Another important factor in the successful use of PDT is the use of the most effective light source to activate the photosensitizers [42]. The light source must ensure the penetration of light to the required depth into the tissues, provide full and uniform illumination of the required zone, the wavelength of the light corresponding to the maximum absorption of the active substance. In this regard, the choice of light source depends not only on the choice of drugs, but also on the depth, size, and characteristics of target tissues [43-45]. The development of PDT technology can aid in the fight against a range of diseases, such as tumors of the colon and bladder, tumors of the brain and spinal cord, and to develop new methods of treatment of skin in plastic surgery and cosmetology [46,47]. Positive results of treatment of proinflammatory diseases by photodynamic therapy show high efficiency of this method in respect of aerobic, facultative, and obligate anaerobic bacteria, and microscopic fungi [48,49].

Photodynamic therapy includes the following mechanism of action: photosensitizer absorbs the energy of the same wavelength from the light source, transmits this energy to the substrate, and destroys the microorganisms by irreversibly oxidizing the cellular components through formation of short-lived reactive molecules [50,51]. Photodynamic action can cause different types of cell death: apoptosis, necrosis, and autophagy. For the development of apoptosis, it is necessary to preserve the integrity of the plasma membrane and a sufficient level of ATP. Chromatin condenses and forms apoptotic cells, and DNA fragmentation occurs when apoptotic cells die. This process of self-destruction of the cell is strictly controlled at the level of regulatory proteins and participating effector enzymes. Proteolytic caspases play a key role in apoptosis. Caspase activation can be initiated both outside and inside the cells. In the first case, the start of the cascade begins with the activation of one of the receptors located on the cell membrane, which perceives the external signal (for example, Fas, TNF, DR-4, DR-5). However, in the second case, which is most likely under photodynamic action, signals for starting apoptosis can come from mitochondria, electron paramagnetic resonance (EPR) and lysosomes. Necrosis is a passive process that does not require energy. In necrosis, there is a violation of the integrity and, accordingly, permeability of the membrane, protein denaturation, and output of the cellular content in the external environment. In the case of autophagy in the cytoplasm of cells, accumulation of membrane bubbles occurs that contain fragments of organelles. When you merge autophagosome with lysosomes, autophagosomes are formed which digest the contents [52,53]. 
The study of the mechanisms of intracellular and intercellular distribution of photosensitizers is an important step in the development of new drugs for PDT. Knowledge of these mechanisms allows for increased efficiency of photodynamic influence on pathological tissues, to predict toxic properties of PS and, thus, to minimize degree of negative influence on normal organs and tissues. Since the basic effector of photodynamic therapy singlet oxygen in its short life (less than $0.04 \mu \mathrm{s}$ ) diffuses in the cell by no more than $0.02 \mu \mathrm{m}$, it is capable of exerting mainly local effects of the PS molecule mucus. Singlet oxygen in cells oxidizes first of all amino acids as a part of proteins (tryptophan, histidine, methionine, cysteine, etc.), ascorbate, and sugars and nucleotides, which are much worse than lipids $[54,55]$. The radius of cytotoxic action of singlet oxygen to the cell does not exceed 0.01-0.02 microns, and its life expectancy in biological systems is less than $0.04 \mu \mathrm{m}$ [56], the small radius of cytotoxic action of singlet oxygen determines the locality of the action, since it damages only biostructures that are in the vicinity of molecules of the photosensitizer. Therefore, the localization of the photosensitizer plays a crucial role in the mechanism of photo-damage, determining intracellular and tissue targets, which will primarily be exposed to photodynamic effects [57]. With the introduction of photosensitizer in the bloodstream, they bind to whey proteins-albumins, globulins, lipoproteins of low or high density - and form complexes, and only a small part of the PS can remain free [58,59]. The possibility of binding to certain whey proteins affects the polarity of the PS.

With an increase in PS hydrophobicity, there is an increase in the probability of binding the dye to low- and high-density lipoproteins [60]. The PS complexes formed with proteins are absorbed by endothelial cells in the capillaries of the bloodstream, after which there is a binding of the dyes with the adventitia of the vessels and the arrival of PS in the extracellular matrix with subsequent accumulation in the cells $[59,60]$. After photoexcitation and subsequent relaxation of the molecule of the photosensitizer is returned to its original state and is able to participate again in the chemical reaction. The whole cycle can be started again after the absorption of a new quantum of light energy. However, after a certain number of cycles, the photosensitizer "burns out", i.e., loses the ability to participate in the photodynamic reaction. This effect is called photobleaching [61].

After intravenous injection the highest concentration of photosensitizer is observed in the liver, kidneys, spleen, and heart, as these organs are characterized by a high level of blood supply and the presence of perforated capillaries. There is a redistribution of PS to other organs and tissues, such as the lungs, intestines, stomach, and skin. The lowest level of accumulation of photosensitizers is noted in the muscles [62].The ways to remove the photosensitizer from the patient's body are determined by the chemical structure of the drug. As a rule, hydrophobic PS are excreted with faeces and bile through the liver, and hydrophilic with urine [63]. Tumor tissues have an increased disposition to the accumulation of PS [64]. This may be due to a number of reasons:

(1) Tumor vessels have increased permeability compared to healthy tissues. Tissue with increased vascular permeability is a weak barrier for most broadcasters moving with blood [65-67].

(2) Low lymph drainage characteristic of tumor area. The decrease in the drainage function of the lymphatic system contributes to the fact that photosensitizers are slowly excreted from the tumor site, which leads to their local accumulation [68].

(3) High speed of proliferation in the tumor, in which there is a high level of expression of low-density lipoprotein receptors, binding a large number of hydrophobic molecules of photosensitizer [69].

(4) Lower $\mathrm{pH}$ value of the tumor than in healthy tissues. The main reason for strengthening the accumulation of photosensitizers in the acidification of the environment is to increase the lipophilicity of the drug, if protonated [70].

(5) Abnormal structure of the tumor stroma, characterized by increased intercellular space and increased production of collagen, which binds porphyrins [71].

(6) Large number of macrophages in tumor tissue, which are effective traps for hydrophobic photosensitizers [72]. 
Photosensitizers, received from vessels in the extracellular matrix, can penetrate into the cell either by diffusion or by receptor-mediated endocytosis (clathrin- and caveolin-dependent pathways). Large aggregates or particles containing PS can be absorbed by the cell by phagocytosis. In the case of endocytosis photosensitizer mainly enters lysosomes. The specific method of penetration of PS into the cell depends primarily on the size of molecules and their ability to aggregate. Modern scientific literature provides a detailed description of the mechanism of penetration of various sensitizers in tumor cells by diffusion [73], endocytosis [74] and phagocytosis [75]. In References [76,77] it was shown that after the PDT procedure it is possible to recalibrate the PS. This phenomenon can cause damage to non-target subcellular structures.

Currently, PDT has attracted a lot of attention as a noninvasive and safe method for the treatment of cancer $[78,79]$. Special attention is paid to the study of the possibility of using free radicals in the treatment of diseases. According to commonly knowledge of free radicals, these reactive forms are harmful for a whole organism. The molecules attack tissues at the cellular level leading to numerous mutations, and this leads to diseases such as neurodegenerative disorders, diabetes, cardiovascular, cancers etc. [80]. Considering the high reactivity of free radicals and their high possibility of damaging cells, these forms can be influential for anticancer therapy. Current medicine pays increasingly more attention to photodynamic therapy as a promising direction for cancer treatment. Based on the physical and photochemical basis of the aforementioned PDT treatment, the basis of treatment is the ability to attack and extinguish the free radical generation of cancers cells. PDT is considered to be a safe and promising therapy. Nevertheless, this action is limited by naturally occurring defense systems which unfortunately help the cancer cells survive and scavenge the radicals. Examples are superoxide dismutase and glutathione which uphold the normal functioning organism and counteract the negative influence of free radicals and oxidative stress [81]. Some terms should be retained for cancer treatment. Firstly, the therapy should lead to irreversible damage of the cancer cells, the destruction should not include healthy tissues/cells and, most significantly, the damage must lead to the total destruction of tumor cells present in concrete tissue [82]. In view of this, a promising approach seems to be in connection of traditional therapy (i.e., chemotherapy) with PDT. Continuous exploration in this medical field allows us to infer the effects of synergy [83]. The most significant cases of the use of PDT and its connection with other antitumor therapies are presented below.

Cancer treatment is not the only application of this technique in medicine: due to the presence of its antibacterial effect, therapy can be applied to many diseases, including root canal treatment of purulent diseases, anti-acne therapy, psoriasis and herpes therapy and physical damage [84]. The progress of scientists in the field of development of light sources and synthesis of new active substances suggests that PDT is one of the most promising and quickly developing techniques in the diagnosis and treatment of various diseases.

\section{Applications of Metal-Based Nanoparticles in PDT}

It is no secret that currently the use of nanotechnology is gaining in popularity and affects an increasing number of scientific fields [85-93]. Nanomaterials are usually easily able to form complex compounds with other substances, including organic materials. At the same time, the developed surface of nanoparticles leads to its increased chemical activity, which makes it possible to use oxide nanoparticles to suppress the growth of pathogenic bacteria, including those resistant to antibiotics [94,95]. Irradiation of nanoparticles with relatively low-power radiation can lead to photostimulated reactions on the surface of nanoparticles. Such reactions-in particular, the generation of singlet oxygen - are used in photodynamic therapy. Formed complexes possess new properties. Therefore, nanoparticles can be in contact with nucleic acids and proteins embedded in membranes, to penetrate into cell organelles by altering the functions of the bio-structures $[96,97]$. The development of knowledge in the application of nanoparticles has led to the possibility of using this technology in the PDT method [98]. Recent studies have shown that metal-based nanoparticles can be used as photosensitizers, delivery vehicles, and upconversion tools [99]. Dispersions, suspensions, and sols of 
metal nanoparticles are of interest among various forms of nanoscale material use. Their advantage lies in their relatively narrow size and shape distribution and long period of activity. There is reason to believe that stable nanoparticles of metals in water dispersions will find useful applications in biology and medicine. Currently, a number of studies are being carried out to research the possibility of using nanoparticles based on molybdenum oxide, $\mathrm{TiO}_{2}, \mathrm{ZnO}$, and tungsten oxide as photosensitizers in PDT [100-102].

\subsection{Gold Nanoparticles}

Gold is one of the most popular materials for nanoparticles used in medicine [103]. One of the directions in cancer therapy is connected with the heating of gold particles by IR laser radiation. A special feature of metal nanoparticles is the presence of resonant absorption of electromagnetic energy for cases when the size of the nanoparticles is much smaller than the wavelength. This absorption is associated with the surface plasmon resonance, which is the collective oscillation of electron gas on the surface of the nanoparticle. For most metals, the wavelength of plasmon resonance lies in the region of visible and shorter waves. For example, the surface plasmon resonance of a gold nanostar placed in water lies close to $520 \mathrm{~nm}$ [104].

The technology of heating gold nanoparticles by infrared laser radiation for the purpose of local thermal damage of cells was first proposed in Reference [105]. The successful application of this technology in the field of cancer treatment was considered in Reference [106]. Due to the fact that the heating of gold nanoparticles requires a wavelength of about $520 \mathrm{~nm}$, these characteristics do not allow light to penetrate deep into the tissue, for which the most optimal wavelengths are 800-900 nm. This basic research aims to study the synthesis of nanoparticles at surface resonance wavelengths, corresponding to the maximum transparency of body tissue $[107,108]$. The light-absorbing properties of gold nanoparticles (the localized surface plasmon resonance) can be easily regulated by controlling the morphology of the size and shape of the nanostructure of the material in the synthesis process [109]. In recent works, leading scientists have proven that a change in the structure of gold nanoparticles allows to change their features to achieve the most efficient use of this material as a photosensitizer [110,111]. The results of Figure 2 shows that the temperature of mice treated with Au nanoparticles increased significantly under light irradiation. The temperature changes of melanoma tumor transplanted mice under 808 and $980 \mathrm{~nm}$ laser irradiation were 12.6 and $10.5^{\circ} \mathrm{C}$, respectively [110]. The results of $808 \mathrm{~nm}$ laser irradiation are caused by nanomaterial-mediated photothermal (NmPTT) effect, while the results of the $980 \mathrm{~nm}$ irradiation are considered to be the result of the combination of nanomaterial-mediated photodynamic therapeutic (NmPDT) and NmPTT effects.
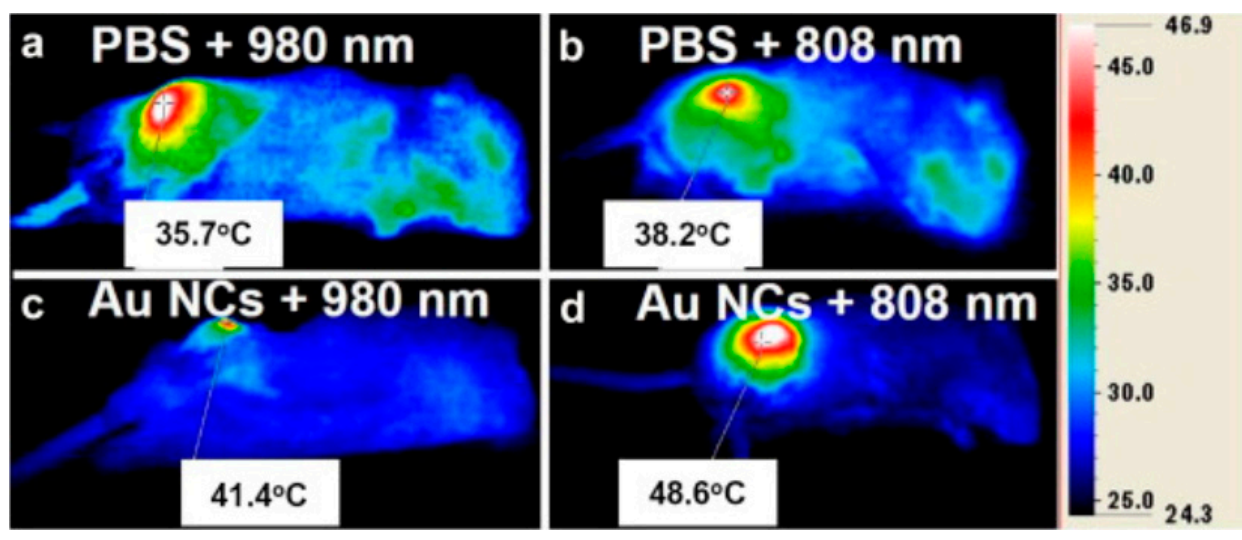

Figure 2. In vivo photothermal images of mice treated with phosphate buffer solution (PBS) and $\mathrm{Au}$ nanoparticles under 808, 915 and $980 \mathrm{~nm}$ laser $\left(150 \mathrm{~mW} / \mathrm{cm}^{2}\right.$ power) (Reproduced with permission [110]). 
In Reference [112], gold nanoparticles with a particle size of 2-4 nm were obtained using a hydrophobic thiol group containing PS, namely phthalocyanine (PC), as a stabilizing agent. It should also be noted that gold nanoparticles are not only photosensitizers, but also have found considerable use in the field of delivery vehicles. In Reference [113], it was shown that, due to targeted delivery through the use of gold nanoparticles, the efficiency of photodynamic therapy has significantly improved. In addition, it did not reveal any toxic action of the conjugates if introduced into the body at therapeutic doses. These results make it possible to conclude that gold is one of the most promising materials in the field of development of PDT technology [114].

\subsection{Silver Nanoparticles}

Silver is one of the strongest-known natural antibiotics and has been used by humans to kill a variety of microorganisms for many years. Colloidal nanosilver is a product consisting of microscopic silver nanoparticles suspended in demineralized and deionized water. Typical silver nanoparticles have a size of $20-25 \mathrm{~nm}$. They have an extremely large specific surface area, which increases the contact area of silver with bacteria or viruses, significantly improving its bactericidal action. Thus, the use of silver in the form of nanoparticles allows the concentration of silver to reduce hundreds of times while maintaining all bactericidal properties. In Reference [115], a wide-ranging study was conducted to examine the effect of silver ions on bacteria. The use of nanoparticles of noble metals (including silver) has found wide application as a technology of container delivery of photosensitizers to target tissues. The action of silver nanoparticles in combination with conjugation in such nanocontainers of photosensitizers can lead to a significant increase in the efficiency of fault detection and isolation (FDI) microorganisms due to the bimodal action of such nanocomposites $[116,117]$. The formation and stabilization of nanosized colloidal metal particles demands careful attention to the preparation conditions and to the presence of stabilizers. Nanoparticles of silver, gold, platinum, and copper have been prepared by various methods, but most of their shapes have been limited to spheres [118]. Thus, silver nanoparticles are a promising and effective approach to enhance photodynamic action on microorganisms, as well as their safety for mammalian cells for photodynamic therapy of tumors.

\subsection{Copper-Based Nanoparticles}

Copper is a trace element vital for the human body. According to recommendations, the daily demand for copper is about $900 \mu \mathrm{g}$. When copper deficiency decreases phagocytic activity of granulocytes and synthesis of immunoglobulins, immunodeficiency occurs. An important biological role of copper is to participate in the processes of proliferation and differentiation of cells. It is experimentally proved that copper gluconate $\left(\mathrm{Cu}^{2+}\right)$ in immunodeficiency contribute to the increase of IgG level, prevent the appearance of malignant cells, and enhance the effect of anticancer protection. On the contrary, copper deficiency increases the probability of neoplasms. During the course of pathological processes, the body accumulates information for the bank of immunological memory. As a result, specific antibodies in the synthesis involve copper. In case of repeated penetration into the body of a known antigen, the acquired immunity is used, so the immune reaction proceeds faster and more clearly, i.e., copper has immunomodulatory properties [119]. Copper sulfide nanoparticles are also widely used in the field of PDT techniques. In modern research both the drug-delivery property in the target tissue and the photodynamic activity of the copper-based particles themselves are described in detail in Reference [120]. In Figure 3, B16 cells treated with plasmonic copper sulfide $\left(\mathrm{Cu}_{2-x} \mathrm{~S}\right)$ showed stronger 2,7-dichlorofluorescein (DCF) fluorescence signal under near infrared light irradiation. The enhancement of the signal intensity is in accordance with the results of electron spin resonance and fluorescence analysis. It is proved that $\mathrm{Cu}_{2-x} \mathrm{~S}$ nanocrystal is involved in the PDT process and can only induce the reactive oxygen species to trigger the biological reaction under the condition of near-infrared light irradiation. 


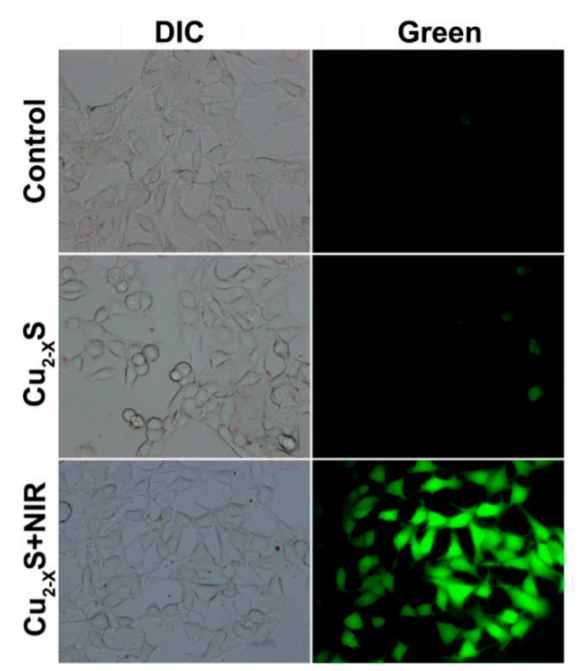

Figure 3. Visible light and fluorescence images of B16 cells incubated with plasmonic $\mathrm{Cu}_{2-\mathrm{x}} \mathrm{S}$ nanocrystals for $6 \mathrm{~h}$ (Reproduced with permission [120]).

$\mathrm{CuS}$ nanoparticles have a broad absorption from 700 to $1100 \mathrm{~nm}$. This property allows heat to be generated by particles and near-infrared light, which can be harnessed to kill cancer cells [121]. In Reference [122] it was shown that CuS nanoparticles are effective agents for both PTT and PDT. The CUS nanoparticles produce both heat and reactive oxygen species when excited by laser and show strong anticancer effects. In Reference [123] it was proposed to use a new method of synthesis of gold nanocubes based on copper oxide nanoparticles. This method differs in economic efficiency and allows the use of the received particles as agents for carrying out photothermal therapy with simultaneous visualization of process by a photoacoustic method.

As a new type of agent for treatment of cancer, CuS nanoparticles are characterized by their low cost, simple and easy preparation as well as small size for surface modification. The other efficient cancer treatment method is PDT. The photosensitizers (PSs) are used to generate highly reactive oxygen species (ROS) including hydroxyl radicals $(\% \mathrm{OH})$, singlet oxygen $\left(1 \mathrm{O}_{2}\right)$, and peroxides $(\mathrm{R}-\mathrm{O}-\mathrm{O} \%)$ for destroying cancer cells by photoexcitation [124,125]. For clinical applications, ideal PSs are supposed to occur at a wavelength between 700 and $1000 \mathrm{~nm}$ since human tissue is penetrable at this energy level. CuS nanoparticles are gaining more and more attention in PTT and PDT for their unique physicochemical characteristic [126]. However, the mechanisms for CuS nanoparticles as PTT and PDT agents are not yet clear. In this paper, we will concentrate on the mechanism studies by evaluation CuS nanoparticles as effective agents for simultaneous PTT and PDT on cancers.

\subsection{Magnetic Nanoparticles}

Magnetic nanoparticles are of particular interest for research and have great potential in their application in biology and medicine. These nanoparticles can affect certain target tissues in the body, without having a toxic effect on healthy tissues. In order to control and contain these particles, an adjustable magnetic field orientation is applied [127]. Toxicity of oxide nanoparticles is low in comparison with metal nanoparticles, therefore they are used for realization of unique methods, such as delivery vehicles in thermal therapy, when heated by laser or microwave radiation to the destruction temperature of the pathological tissue, etc. [128-130]. Various particles coated with a metal shell are usually used under the action of magnetic nanoparticles. The greatest attention is on particles with a shell of magnetite $\mathrm{Fe}_{3} \mathrm{O}_{4}$, which, thanks to their spherical shape and narrow size distribution, have found wide application in the diagnosis and treatment of various diseases [131]. In Reference [131], a study of the effects of chemo- and photothermal therapy of cancer tumors was conducted. Mesoporous magnetic nanoclusters of gold were used as carriers and therapeutic agents. 
As a result of the study, mice were found to have significant inhibition of tumor growth and metastasis due to the therapeutic effect and targeted delivery of gold nanoclusters.

\subsection{Metal-Organic Frameworks in PDT}

Metal-organic frameworks (MOFs) are organic-inorganic hybrid materials, which form through the self-assembly of organic ligands and metallic clusters through the coordination bonds with intramolecular pores. The arrangement of organic ligands and metallic clusters has obvious directivity, which can form different adsorption properties, optical properties, and electromagnetic properties. The MOFs have the advantages of high porosity, low density, large specific surface area, regular channel, adjustable aperture, and diverse topology and tailoring.

In recent years, MOFs have been used in PDT. Nanoscale metal-organic frameworks (NMOFs) have shown great potential in biomedicine owing to their structural/chemical diversities, high molecular loading capacities, and intrinsic biodegradability. In 2014, Lu et al. [132] reported the first application of nanoscaled MOF in PDT. They reported the rational design of a Hf-porphyrin nanoscale metal-organic framework, DBP-UiO, as an exceptionally effective photosensitizer for PDT of resistant head and neck cancer. DBP-UiO displayed greatly enhanced PDT efficacy both in vitro and in vivo, leading to complete tumor eradication in half of the mice receiving a single $\mathrm{DBP}-\mathrm{UiO}$ dose and a single light exposure. After that, more applications of nanoscaled MOFs in PDT were reported [36,133]. The MOFs have already become a new type of representative metal-based nanoparticles applied in PDT applications.

\section{Potential Toxicity of Metal-Based Nanoparticles}

Metal nanoparticles have received increasing interest in many fields, including the PDT applications mainly discussed in this review. However, due to their special physical and chemical properties, nanoparticles may have adverse effects on the level of subcellular and protein in organs and tissues. Properties such as chemical composition, small size, high surface-area-to-volume-ratio, aggregation behavior, functional groups and so on would significantly influence the toxicity of nanoparticles for living organisms $[134,135]$. When particle size decreases, some metal-based nanoparticles exhibit increased toxicity, even though the same material is relatively inert in its bulk form, such as $\mathrm{Ag}$, $\mathrm{Au}$ and $\mathrm{Cu}$. Nanoparticles also will interact with enzymes and proteins in mammalian cells, which can interfere with antioxidant defense mechanisms, lead to the generation of reactive oxygen species, the initiation of inflammatory reactions, and disturbance and destruction of mitochondria, leading to cell apoptosis or necrosis. Thus, there is still a lot of work needed to be done to recognize the potential toxicity of metal-based nanoparticles in PDT applications and determine whether the benefits exceed the risks associated with them.

Compared with the photosensitizers traditionally used in photodynamic therapy, metal-based nanoparticles have the advantages of high loading, slow degradation, long cycle time, and targeted and controllable release. Thus, they are often used as target drug delivery carriers in PDT applications. However, the interaction between metal-based nanoparticles and cells needs to be considered from the entry routes of various possible pathways (e.g., through skin [136], gastrointestinal tract [137], blood circulation, lungs [138], etc.) into potential target organs. After nanoparticles enter the body circulation, they may affect the toxicity of the endothelial cell membrane and/or destroy the tight junctions of the blood-brain barrier, and then enter the brain environment [139]. Compared with larger size materials, $\mathrm{Ag}$ and $\mathrm{Cu}$ nanoparticles are more likely to enter human organs and circulatory systems, and cannot be detected by normal phagocytic defense mechanisms, causing them to enter the blood or move through the blood-brain barrier into the nervous system [140]. In addition, $\mathrm{Ag}, \mathrm{Cu}$ and $\mathrm{Al}$ nanoparticles can induce oxidative stress reaction and produce damaging free radicals on endothelial cell membrane [139]. This interference may also lead to dysfunction of blood-brain barrier, leading to the entry of metal-based nanoparticles into the central nervous system. 
In addition to penetrating the blood-brain barrier [141], metal-based nanoparticles also can penetrate the blood-testis barrier (especially Leydig cells) [142], thus causing reproductive problems. Recent studies show that certain metal-based nanoparticles can attenuated the proliferation of spermatogonial stem cells in vitro [143]. However, the interaction between metal-based nanoparticles and the normal function of human body has not been systematically studied and understood. In view of the profound impact of nanoparticles on human health, it is foreseeable that researchers will continue to systematically study and evaluate them through a variety of scientific methods. In this section, the potential toxicity of several kinds of specific metal-based nanoparticles are discussed and organized according to elemental compositions with an emphasis on the evaluation of toxicity.

\subsection{Gold Nanoparticles}

There are an increasing number of studies on the potential toxicity of Au-based nanoparticles. According to currently published data, the toxicity of Au nanoparticle is highly dependent on its synthetic methods and its shape, size, surface chemical properties and surface charge.

In vivo toxicity studies of intravenous colloid $\mathrm{Au}$ nanoparticles in mice showed that smaller particles (10 50 nm) were more toxic than larger particles (100 200 nm). Pan et al. [144] systematically studied the water-soluble gold nanoparticle of triphenylphosphine derivatives ranging in size from 0.8 to $15 \mathrm{~nm}$, and tested the toxicity of these particles in four cell lines (including connective tissue fibroblasts, epithelial cells, macrophages and melanoma cells). These cell lines are most sensitive to gold nanoparticles $1.4 \mathrm{~nm}$ in size, which leads to a change in the IC50 value within the cell line in the range of 30 to $56 \mu \mathrm{M}$, depending on the combination of particular $1.4 \mathrm{~nm}$ gold nanoparticles and the cell line. When the size of gold nanoparticles is $15 \mathrm{~nm}$, even the concentration of Tauredon (gold thiomalate) under 60 or 100 times concentration is still nontoxic. Figure 4 shows typical pictures of healthy cells and necrotic cells treated with $110 \mu \mathrm{M}$ Au nanoparticles (1.4 nm in diameter) [144]. The untreated cells treated show double negative staining under annexin $\mathrm{V}$ and propidium iodide (Figure 4a,b), whereas the cells treated with Au nanoparticles present double positive (Figure 4c,d).
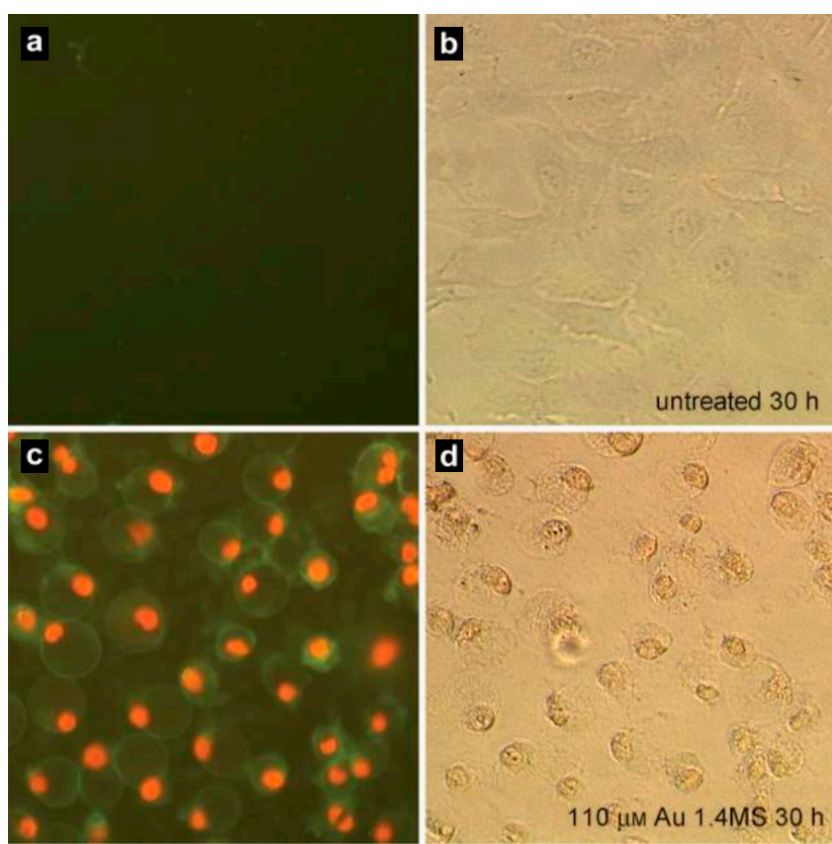

Figure 4. Fluorescence pictures of HeLa cells for the detection of apoptosis (annexin V, green fluorescence) and necrosis (propidium iodide, red fluorescence). (a,b) Untreated cells strained double negative for annexin $\mathrm{V}$ and propidium iodide, $(\mathbf{c}, \mathbf{d})$ necrotic cells presented green and red fluorescence for annexin V and propidium iodide, respectively. (Reproduced with permission [144]). 
Wang et al. [145] studied the effect of shape of Au nanoparticles on toxicity. It was found that cetyltrimethylammonium bromide (CTAB) coated Au nanoparticles were more toxic to human HaCaT keratinocytes than spherical ones $(\sim 30 \mathrm{~nm})$. MTT test, absorption spectroscopy and transmission electron microscope (TEM) were applied to analysis the cytotoxicity of gold nanomaterial. The researchers found the toxicity of Au nanoparticles is a result of a combination of factors, which is difficult to understand by single-factor analysis. The recent results from Li's group showed that $\mathrm{Au}$ nanoparticles with the size of $20 \mathrm{~nm}$ average were nontoxic to lung fibroblasts when citric acid decreased [146]. However, the Au nanoparticles did produce a large amount of oxidative DNA damage and downregulated the DNA damage and the expression of cell-cycle genes.

There is still much controversy about whether Au nanoparticles are toxic in the academic community. In other words, although the results for toxicity of Au nanoparticles seem to be bleak, many other studies have reported them as nonreactive and nontoxic to body cells. Shukla's group [147] reported that the toxicity of $3.5 \mathrm{~nm}$ Au nanoparticles lysine to macrophages was $100 \mu \mathrm{M}$ after $72 \mathrm{~h}$ exposure, and there has no significant effect on the secretion of proinflammatory cytokines TNF- $\alpha$ or IL-1 $\beta$. Furthermore, Conner and co-workers [148] also reported that spherical Au nanoparticles with different sizes $(4,12$, and $18 \mathrm{~nm})$ and surface modifiers are all nontoxic to human leukemic cells. These studies have tried to indicate that the surface chemistry and synthesis conditions of $\mathrm{Au}$ nanoparticles play important roles in modifying biological reactions.

\subsection{Silver Nanoparticles}

Carlson et al. [149] found that the toxicity of silver nanoparticles is also related to size. They further found that the toxicity mechanism of silver nanoparticles is mainly mediated by oxidative stress. They systematically evaluated the effects of three known sizes of silver nanoparticles $(15 \mathrm{~nm}, 30 \mathrm{~nm}$ and $55 \mathrm{~nm}$ ) on cell viability. Alveolar macrophages were selected as research objects and their potential roles in the initiation of oxidative stress were studied. The cells exposed to silver nanoparticles will produce abnormal morphology and adhesion characteristics, and $24 \mathrm{~h}$ later, there will be obvious nanoparticle uptake. The researchers used mitochondria and cell membrane activity as well as reactive oxygen species (ROS) as toxicity assessment indexes. After $24 \mathrm{~h}$ of exposure, the activity index decreased sharply with the dosage increase of Ag $15 \mathrm{~nm}$ and Ag $30 \mathrm{~nm}$ nanoparticle $(10-75 \mathrm{~g} / \mathrm{mL})$. When the concentration of $\mathrm{Ag} 15 \mathrm{~nm}$ was $50 \mathrm{~g} / \mathrm{mL}$, the level of ROS increased by more than 10 times, indicating that the cytotoxicity of $\mathrm{Ag} 15 \mathrm{~nm}$ might be mediated by oxidative stress. In addition, by measuring the release of cytokine/chemokine levels (including tumor necrosis factor (TNF- $\alpha$ ), macrophage inhibitory protein (MIP-2), and interleukin-6 (IL-6)) in the medium, the activation of the release of traditional inflammatory mediators was detected. After exposure to $\mathrm{Ag} 15 \mathrm{~nm}$ nanoparticles for $24 \mathrm{~h}$, the release of TNF- $\alpha$, MIP-2, and IL-1 $\beta$ could show obvious inflammatory reaction. Figure 5 presents the endocytosis of Ag nanoparticles with different sizes by alveolar macrophages. Obvious uptake of Ag nanoparticles can be found after $24 \mathrm{~h}$ incubation, and the nanoparticles also tend to form micron-sized aggregations both outside and inside the macrophages. 

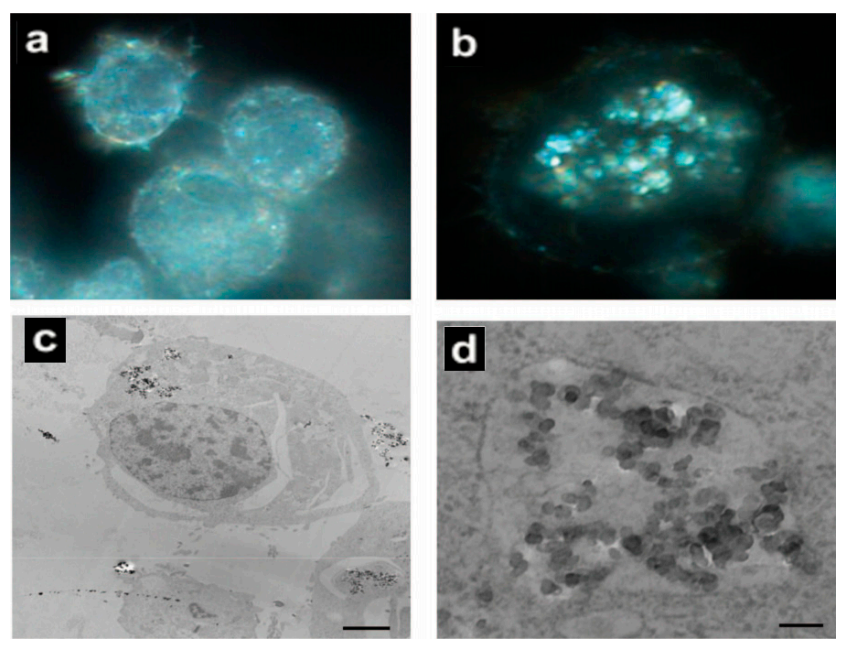

Figure 5. Comparative study on the uptake of Ag nanoparticles by alveolar macrophages. (a,b) Light microscope images illustrating uptake of nanoparticles in alveolar macrophages at $100 \times$ oil magnification after $6 \mathrm{~h}$. (a) Control; (b) Cells treated with $30 \mathrm{~nm}$ Ag nanoparticles $(25 \mu \mathrm{g} / \mathrm{mL})$ for $6 \mathrm{~h}$; (c,d) Low-magnification and high-magnification TEM images of cells that internalized $55 \mathrm{~nm} \mathrm{Ag}$ nanoparticles $(25 \mu \mathrm{g} / \mathrm{mL})$ into vacuoles after $24 \mathrm{~h}$ incubation. The scale bars are $2 \mu \mathrm{m}$ and $500 \mathrm{~nm}$, respectively. (Reproduced with permission [149]).

Kim and colleagues [150] used Sprague-Dawley rats as research objects and tested the oral toxicity of silver nanoparticles $(60 \mathrm{~nm})$ for 28 days. Male and female rats were selected to conduct a controlled trial of low-dose group (30 mg/ $\mathrm{kg})$, medium-dose group ( $300 \mathrm{mg} / \mathrm{kg}$ ) and high-dose group $(1000 \mathrm{mg} / \mathrm{kg})$. After 28 days of oral toxicity test, blood biochemical and hematological examinations were carried out. The histopathological examination and the distribution of silver nanoparticles in the rats' bodies were also studied. The results showed that there was no significant variation in weight and dose of silver nanoparticles in male and female rats. However, the values of alkaline phosphatase and cholesterol in the subjects showed a significant dose-dependent variation, and silver nanoparticles more than $300 \mathrm{mg}$ may lead to slight liver damage. That is, silver nanoparticles do not cause genotoxicity in male and female rats. However, the tissue distribution of silver nanoparticles did show a dose-dependent accumulation of silver in all examined tissues. At the same time, the researchers noticed a sex-related difference in the accumulation of silver nanoparticles, and the dose of silver nanoparticles in the kidney of female rats was two-times higher than that in the kidney of male rats. Similar study using Sprague-Dawley rats was also performed by Ji et al. [151].

The influence of silver nanoparticles on gene expression has also been investigated by researchers. The effects of silver nanoparticles with the diameter of $25 \mathrm{~nm}$ on gene expression in different brain regions of mice were systematically studied by Ali's group [152]. Male adult C57BL/6N mice were injected with $100 \mathrm{mg} / \mathrm{kg}, 500 \mathrm{mg} / \mathrm{kg}$ or $1000 \mathrm{mg} / \mathrm{kg}$ doses of silver nanoparticles, respectively, and sacrificed $24 \mathrm{~h}$ after injection. Then the brain tissues from different regions were quickly removed and divided into caudate nucleus, frontal cortex, and hippocampus. The total RNA was isolated from the three brain regions collected, and real-time RT-PCR analysis was carried out using mouse oxidative stress and antioxidant defense arrays. The results showed that the gene expression in caudate nucleus, frontal cortex and hippocampus of mice injected with $25 \mathrm{~nm}$ silver nanoparticles was significantly different, which proved that the Ag nanoparticles can induce apoptosis and produce neurotoxicity by inducing altering gene expression and free radical induced oxidative stress.

\subsection{Copper Nanoparticles}

Histological analysis showed that $\mathrm{Cu}$ nanoparticles had serious toxicological effects and could seriously damage the kidney, liver and spleen of mice [153]. The cytotoxicity of copper nanoparticles 
was systematically studied by Song et al. [154]. In order to test the cytotoxicity of copper nanoparticles, the researchers added four different sizes of copper nanoparticles (25, 50, 78 and $100 \mathrm{~nm})$ and a micron grade of copper particles ( $500 \mathrm{~nm}$ ) to the fish cell lines (PLHC-1 and RTH-149) and mammalian cell lines (H4IIE and HepG2), respectively. The results show that the size, morphology, and ion release of copper nanoparticles will have an important effect on their toxicity.

Some researchers have also thought it important to distinguish the effects of dissolved metal and metal-based nanoparticles. In order to solve this problem, Barber's group [155] used zebrafish to compare the toxicity of soluble copper and copper nanoparticles $(80 \mathrm{~nm})$. The results showed that nanocopper was highly toxic to zebrafish. Although the copper concentration in the copper nanoparticles suspension will accumulate above a certain concentration, it is not enough to explain the mortality of zebrafish under the environment of nanocopper. Histological and biochemical analysis showed that gill was the primary aggregation organ of nanoparticles. In order to further study the effect of copper nanoparticles on the gills of zebrafish, the zebrafishes were placed in the suspension of copper nanoparticle (100 g/L concentration) and soluble copper solution at the same concentration, respectively. Under these experimental conditions, the nanoscale copper produced completely different morphological effects and global gene expression patterns in the gills, proving that the insoluble copper nanoparticles also affect the morphology of the gills of zebrafish.

The sources and toxicological effects of copper nanoparticles were studied by Yao's group [156] using stress-responsive bacterial biosensor arrays. According to the reaction of the biosensor, the researchers can induce DNA damage, protein damage and cell membrane damage in addition to inducing the oxidative stress reaction in Escherichia coli, and eventually cause to the inhibition of cell growth. Further studies using enzyme detoxification analysis revealed that the toxicity of copper nanoparticles was related to the formation of $\mathrm{H}_{2} \mathrm{O}_{2}$ (as shown in Figure 6a). In addition, the results of transmission electron microscope show that the copper nanoparticles will be adsorbed by cells and quickly phagocytic, while the copper particles in micron size are relatively stable in the cell system and will not produce toxicity, which proves the importance of toxicity assessment of materials on nanoscale. Figure $6 \mathrm{~b}$ shows the transmission electron microscope results of Escherichia coli cells after exposure to $80 \mathrm{mg} \cdot \mathrm{L}^{-1} \mathrm{Cu}$ nanoparticles for $30 \mathrm{~min}$, in which clear damage to the cell membrane can be found.

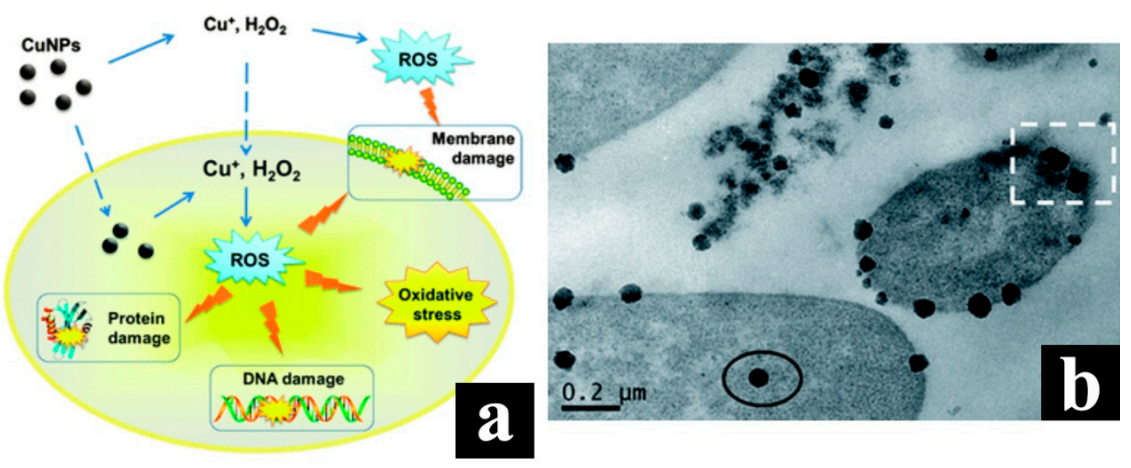

Figure 6. (a) Schematic diagram of the main toxicity mechanism of $\mathrm{Cu}$ nanoparticles; (b) Transmission electron microscope results of Escherichia coli cells after exposure to $80 \mathrm{mg} \cdot \mathrm{L}^{-1} \mathrm{Cu}$ nanoparticles for $30 \mathrm{~min}$ (Reproduced with permission [156]).

In Table 1 we list several more examples of the toxicity studies on $\mathrm{Au}, \mathrm{Ag}, \mathrm{Cu}$, and other metal-based nanoparticles both in vitro or in vivo 
Table 1. Selected comparative toxicity studies.

\begin{tabular}{|c|c|c|c|c|}
\hline Nanoparticles & Target & Dose & Result & References \\
\hline $\mathrm{Au}$ & Mice (in vivo) & $2 \times 10^{5} \mathrm{PPB}$ & $\begin{array}{l}\text { Uptake of nanoparticles occurred in the } \\
\text { small intestine }\end{array}$ & [157] \\
\hline $\mathrm{Ag}$ & Zebrafish (in vivo) & 5-100 $\mu \mathrm{g} / \mathrm{mL}$ & Dose-dependent toxicity in embryos & [158] \\
\hline $\mathrm{Ag}, \mathrm{Cu}, \mathrm{Al}$ & Mice and Rat (in vivo) & $30-50 \mathrm{mg} / \mathrm{kg}$ & Blood-brain barrier penetration & [159] \\
\hline $\mathrm{Ag}, \mathrm{Mn}$ & PC-12 cells (in vitro) & $1-100 \mu \mathrm{g} / \mathrm{mL}$ & Cell shrinkage and irregular membrane & [160] \\
\hline $\mathrm{Ag}, \mathrm{TiO}_{2}$ & $\begin{array}{l}\text { Murine macrophage cell line } \\
\text { (in vitro) }\end{array}$ & $5 \mu \mathrm{g} / \mathrm{mL}$ & Aggregates of nanoparticles & [161] \\
\hline $\mathrm{TiO}_{2}$ & Mice (in vivo) & $5 \mathrm{~g} / \mathrm{kg}$ & Show histopathological effects & [162] \\
\hline $\mathrm{Cu}, \mathrm{Mn}$ & PC- 12 cells (in vitro) & $10 \mu \mathrm{g} / \mathrm{mL}$ & Genes expression altered & [163] \\
\hline $\mathrm{Al}, \mathrm{Al}_{2} \mathrm{O}_{3}$ & Rat (in vivo) & $25-250 \mu \mathrm{g} / \mathrm{mL}$ & Phagocytosis hindered & [164] \\
\hline $\mathrm{Cu}$ & Zebrafish (in vivo) & $0.25-1.5 \mathrm{mg} / \mathrm{L}$ & Biochemical, histopathological changes & [155] \\
\hline
\end{tabular}

\section{Summary}

PDT is undoubtedly a very promising direction for cancer treatment. However, the application of PDT is hindered by classic PSs due to their poor water solubility and limited light-penetration depth. Thus, PDT is still not recognized as a first-line treatment method. The application of nanoparticles, especially metal-based nanoparticles, in PDT is a very promising approach for the breakthrough of classic techniques in the near future. Metal-based nanoparticles can be applied as carriers of hydrophobic PSs and deliver them to the sites of different tumors via EPR effect.

In this review, we have comprehensively introduced the applications of $\mathrm{Au}, \mathrm{Ag}, \mathrm{Cu}$ and other metal-based nanoparticles in PDT. Classic PSs have defects such as low solubility, poor tumor selectivity and undesirable pharmacokinetics, but a suitable carrier platform can solve these problems to a certain extent. However, the application of metal-based nanoparticles is a double-edged sword. Researchers found they may show toxicity to cells, animals, and even humans. Although some researchers claim that the application of metal-based nanoparticles can be nontoxic under specific controlled conditions, concerns still exist and prevent them from being used in practical clinical treatments. In fact, rare metal-based nanoparticles have been approved by the FDA for clinical application. There is still a long way to go from research results to practical applications. Furthermore, we should realize that there is still great potential for efficient promotion of PDT, which can be achieved by optimizing PDT parameters, improving stability of the PS carrier, improving upconversion efficiency, etc. Since PDT involves multidisciplinary fields, frequent communication between researchers, clinicians, engineers, and industrial producers is badly needed to share and discuss cutting-edge opportunities and challenges in the field. Only in this way can PDT eventually become a frontier method for cancer diagnosis and interventional treatments with practical application values.

Funding: This work was supported by the National Natural Science Foundation of China (Grant No. 51673020 and No. 51173015).

Acknowledgments: This work was supported by the National Natural Science Foundation of China (Grant No. 51673020 and No. 51173015).

Conflicts of Interest: The authors declare no conflicts of interest.

\section{References}

1. Dobson, J.; de Queiroz, G.F.; Golding, J.P. Photodynamic therapy and diagnosis: Principles and comparative aspects. Vet. J. 2018, 233, 8-18. [CrossRef] [PubMed]

2. Idris, N.M.; Gnanasammandhan, M.K.; Zhang, J.; Ho, P.C.; Mahendran, R.; Zhang, Y. In vivo photodynamic therapy using upconversion nanoparticles as remote-controlled nanotransducers. Nat. Med. 2012, 18, 1580-1585. [CrossRef] [PubMed]

3. Cheng, Y.; Cheng, H.; Jiang, C.; Qiu, X.; Wang, K.; Huan, W.; Yuan, A.; Wu, J.; Hu, Y. Perfluorocarbon nanoparticles enhance reactive oxygen levels and tumour growth inhibition in photodynamic therapy. Nat. Commun. 2015, 6. [CrossRef] [PubMed] 
4. Poon, I.K.H.; Lucas, C.D.; Rossi, A.G.; Ravichandran, K.S. Apoptotic cell clearance: Basic biology and therapeutic potential. Nat. Rev. Immunol. 2014, 14, 166-180. [CrossRef] [PubMed]

5. Huang, H.C.; Mallidi, S.; Liu, J.; Chiang, C.T.; Mai, Z.; Goldschmidt, R.; Ebrahim-Zadeh, N.; Rizvi, I.; Hasan, T. Photodynamic Therapy Synergizes with Irinotecan to Overcome Compensatory Mechanisms and Improve Treatment Outcomes in Pancreatic Cancer. Cancer Res. 2015, 76, 1066-1077. [CrossRef] [PubMed]

6. He, C.; Duan, X.; Guo, N.; Chan, C.; Poon, C.; Weichselbaum, R.R.; Lin, W. Core-shell nanoscale coordination polymers combine chemotherapy and photodynamic therapy to potentiate checkpoint blockade cancer immunotherapy. Nat. Commun. 2016, 7, 12499. [CrossRef] [PubMed]

7. Yu, M.; Xu, X.; Cai, Y.; Zou, L.; Shuai, X. Perfluorohexane-cored nanodroplets for stimulations-responsive ultrasonography and $\mathrm{O}_{2}$-potentiated photodynamic therapy. Biomaterials 2018, 175, 61-71. [CrossRef] [PubMed]

8. Kachynski, A.V.; Pliss, A.; Kuzmin, A.N.; Ohulchanskyy, T.Y.; Baev, A.; Qu, J.; Prasad, P.N. Photodynamic therapy by in situ nonlinear photon conversion. Nat. Photonics 2014, 8, 455-461. [CrossRef]

9. Yu, M.; Guo, F.; Wang, J.; Tan, F.; Li, N. A pH-Driven and photoresponsive nanocarrier: Remotely-controlled by near-infrared light for stepwise antitumor treatment. Biomaterials 2016, 79, 25-35. [CrossRef] [PubMed]

10. Piao, W.; Hanaoka, K.; Fujisawa, T.; Takeuchi, S.; Komatsu, T.; Ueno, T.; Terai, T.; Tahara, T.; Nagano, T.; Urano, Y. Development of an Azo-Based Photosensitizer Activated under Mild Hypoxia for Photodynamic Therapy. J. Am. Chem. Soc. 2017, 139, 13713-13719. [CrossRef] [PubMed]

11. Rosa, L.P.; da Silva, F.C.; Nader, S.A.; Meira, G.A.; Viana, M.S. In vitro effectiveness of antimicrobial photodynamic therapy (APDT) using a $660 \mathrm{~nm}$ laser and malachite green dye in Staphylococcus aureus biofilms arranged on compact and cancellous bone specimens. Lasers Med. Sci. 2014, 29, 1959-1965. [CrossRef] [PubMed]

12. Xing, R.; Liu, K.; Jiao, T.; Zhang, N.; Ma, K.; Zhang, R.; Zou, Q.; Ma, G.; Yan, X. An Injectable Self-Assembling Collagen-Gold Hybrid Hydrogel for Combinatorial Antitumor Photothermal/Photodynamic Therapy. Adv. Mater. 2016, 28, 3669-3676. [CrossRef] [PubMed]

13. Yan, L.; Miller, J.; Yuan, M.; Liu, J.F.; Busch, T.M.; Tsourkas, A.; Cheng, Z. Improved Photodynamic Therapy Efficacy of Protoporphyrin IX-Loaded Polymeric Micelles Using Erlotinib Pretreatment. Biomacromolecules 2017, 18, 1836-1844. [CrossRef] [PubMed]

14. Duan, X.; Chan, C.; Guo, N.; Han, W.; Weichselbaum, R.R.; Lin, W. Photodynamic Therapy Mediated by Nontoxic Core-Shell Nanoparticles Synergizes with Immune Checkpoint Blockade To Elicit Antitumor Immunity and Antimetastatic Effect on Breast Cancer. J. Am. Chem. Soc. 2016, 138, 16686-16695. [CrossRef] [PubMed]

15. Cruz, É.P.; Campos, L.; Pereira, F.S.; Magliano, G.C.; Benites, B.M.; Arana-Chavez, V.E.; Ballester, R.Y.; Simões, A. Clinical, biochemical and histological study of the effect of antimicrobial photodynamic therapy on oral mucositis induced by 5-fluorouracil in hamsters. Photodiag. Photodyn. Ther. 2015, 12, 298-309. [CrossRef] [PubMed]

16. Zhou, Z.; Song, J.; Nie, L.; Chen, X. Reactive oxygen species generating systems meeting challenges of photodynamic cancer therapy. Chem. Soc. Rev. 2016, 45, 6597-6626. [CrossRef] [PubMed]

17. Li, S.; Chang, K.; Sun, K.; Tang, Y.; Cui, N.; Wang, Y.; Qin, W.; Xu, H.; Wu, C. Amplified Singlet Oxygen Generation in Semiconductor Polymer Dots for Photodynamic Cancer Therapy. ACS Appl. Mater. Interfaces 2015, 8, 3624-3634. [CrossRef] [PubMed]

18. Lucky, S.S.; Soo, K.C.; Zhang, Y. Nanoparticles in Photodynamic Therapy. Chem. Rev. 2015, 115, 1990-2042. [CrossRef] [PubMed]

19. Kennedy, J.C.; Marcus, S.L.; Pottier, R.H. Photodynamic therapy (PDT) and photodiagnosis (PD) using endogenous photosensitization induced by 5-aminolevulinic acid (ALA): Mechanisms and clinical results. J. Clin. Laser Med. Surg. 1996, 14, 289-304. [PubMed]

20. Lan, G.; Ni, K.; Xu, Z.; Veroneau, S.S.; Song, Y.; Lin, W. Nanoscale Metal-Organic Framework Overcomes Hypoxia for Photodynamic Therapy Primed Cancer Immunotherapy. J. Am. Chem. Soc. 2018, 140, 5670-5673. [CrossRef] [PubMed]

21. Eroglu, C.N.; Keskin Tunc, S.; Erten, R.; Usumez, A. Clinical and histological evaluation of the efficacy of antimicrobial photodynamic therapy used in addition to antibiotic therapy in pericoronitis treatment. Photodiagn. Photodyn. Ther. 2018, 21, 416-420. [CrossRef] [PubMed] 
22. Sharma, G.; Kapoor, U.; Juneja, M.; Nagpal, A. Halitosis: Current concepts on etiology, diagnosis and management. Eur. J. Dent. 2016, 10, 292-300. [CrossRef] [PubMed]

23. Abdel-Kader, M.H. History of Photodynamic Therapy. In Photodynamic Therapy; Springer: Berlin/Heidelberg, Germany, 2014; pp. 3-22. [CrossRef]

24. Allison, R.; Moghissi, K.; Downie, G.; Dixon, K. Photodynamic therapy (PDT) for lung cancer. Photodiagn. Photodyn. Ther. 2011, 8, 231-239. [CrossRef] [PubMed]

25. Hasan, T. Photodynamic therapy as a unique enabler of spatiotemporally synchronized cancer combination therapies. Photodiagn. Photodyn. Ther. 2017, 17, A33-A34. [CrossRef]

26. Kaya, E.N.; Köksoy, B.; Yeşilot, S.; Durmuş, M. The effects of axially BODIPY substitution on photodynamic therapy of cancer properties of silicon (IV) phthalocyanine. Photodiagn. Photodyn. Ther. 2017, 17, A56. [CrossRef]

27. Raab, O. Uber die Wirkung fluorescirender Stoffe auf Infusorien. Ztg. Biol. 1900, 39, 524-546.

28. Hausmann, W. Über die sensibilisierende Wirkung des Hämatoporphyrins. Biochem. Z. 1911, 30, $276-316$.

29. Meyer-Betz, F. Untersuchungen über die biologische (photodynamische) Wirkung des Hämatoporphyrins und anderer Derivate des Blut-und Gallenfarbstoffs. Dtsch. Arch. Klin. Med. 1913, 112, 476-503.

30. Policard, A. Etude sur les aspects offerts par des tumeurs experimentales examinees a la lumiere de Wood. C. R. Soc. Biol. 1924, 91, 1423-1424.

31. Dougherty, T.J.; Kaufman, J.E.; Goldfarb, A.; Weishaupt, K.R.; Boyle, D.; Mittleman, A. Photoradiation therapy for the treatment of malignant tumors. Cancer Res. 1978, 38, 2628-2635. [PubMed]

32. Lam, S.; Müller, N.L.; Miller, R.R.; Kostashuk, E.C.; Szasz, I.J.; Leriche, J.C.; Lee-Chuy, E. Predicting the response of obstructive endobronchial tumors to photodynamic therapy. Cancer 1986, 58, 2298-2306. [CrossRef]

33. Banerjee, S.; MacRobert, A.; Mosse, C.; Periera, B.; Bown, S.; Keshtgar, M. Photodynamic therapy: Inception to application in breast cancer. Breast 2017, 31, 105-113. [CrossRef] [PubMed]

34. Li, W.; Peng, J.; Tan, L.; Wu, J.; Shi, K.; Qu, Y.; Wei, X.; Qian, Z. Mild photothermal therapy/photodynamic therapy/chemotherapy of breast cancer by Lyp-1 modified Docetaxel/IR820 Co-loaded micelles. Biomaterials 2016, 106, 119-133. [CrossRef] [PubMed]

35. García Calavia, P.; Chambrier, I.; Cook, M.J.; Haines, A.H.; Field, R.A.; Russell, D.A. Targeted photodynamic therapy of breast cancer cells using lactose-phthalocyanine functionalized gold nanoparticles. J. Colloid Interface Sci. 2018, 512, 249-259. [CrossRef] [PubMed]

36. Park, J.; Jiang, Q.; Feng, D.; Mao, L.; Zhou, H.-C. Size-Controlled Synthesis of Porphyrinic Metal-Organic Framework and Functionalization for Targeted Photodynamic Therapy. J. Am. Chem. Soc. 2016, 138, 3518-3525. [CrossRef] [PubMed]

37. Liu, J.; Zhang, L.; Lei, J.; Shen, H.; Ju, H. Multifunctional Metal-Organic Framework Nanoprobe for Cathepsin B-Activated Cancer Cell Imaging and Chemo-Photodynamic Therapy. ACS Appl. Mater. Interfaces 2017, 9, 2150-2158. [CrossRef] [PubMed]

38. Lu, K.; He, C.; Guo, N.; Chan, C.; Ni, K.; Weichselbaum, R.R.; Lin, W. Chlorin-Based Nanoscale Metal-Organic Framework Systemically Rejects Colorectal Cancers via Synergistic Photodynamic Therapy and Checkpoint Blockade Immunotherapy. J. Am. Chem. Soc. 2016, 138, 12502-12510. [CrossRef] [PubMed]

39. Hong, E.J.; Choi, D.G.; Shim, M.S. Targeted and effective photodynamic therapy for cancer using functionalized nanomaterials. Acta Pharm. Sin. B 2016, 6, 297-307. [CrossRef] [PubMed]

40. Allison, R.R.; Moghissi, K. Photodynamic Therapy (PDT): PDT Mechanisms. Clin. Endosc. 2013, 46, 24. [CrossRef] [PubMed]

41. Golding, J.P.; Kemp-Symonds, J.G.; Dobson, J.M. Glycolysis inhibition improves photodynamic therapy response rates for equine sarcoids. Vet. Comp. Oncol. 2017, 15, 1543-1552. [CrossRef] [PubMed]

42. Kinsella, T.J.; Colussi, V.C.; Oleinick, N.L.; Sibata, C.H. Photodynamic therapy in oncology. Expert Opin. Pharmacother. 2005, 2, 917-927. [CrossRef] [PubMed]

43. Grossman, C.; Carter, S.; Czupryna, J.; Wang, L.; Putt, M.; Busch, T. Fluence Rate Differences in Photodynamic Therapy Efficacy and Activation of Epidermal Growth Factor Receptor after Treatment of the Tumor-Involved Murine Thoracic Cavity. Int. J. Mol. Sci. 2016, 17, 101. [CrossRef] [PubMed]

44. Sun, J.; Wang, X.; Wu, J.; Jiang, C.; Shen, J.; Cooper, M.A.; Zheng, X.; Liu, Y.; Yang, Z.; Wu, D. Biomimetic Moth-eye Nanofabrication: Enhanced Antireflection with Superior Self-cleaning Characteristic. Sci. Rep. 2018, 8. [CrossRef] [PubMed] 
45. Sun, J.; Zhao, Y.; Yang, Z.; Shen, J.; Cabrera, E.; Lertola, M.J.; Yang, W.; Zhang, D.; Benatar, A.; Castro, J.M.; et al. Highly Stretchable and Ultrathin Nanopaper Composites for Epidermal Strain Sensors. Nanotechnology 2018. [CrossRef] [PubMed]

46. Huang, Z. A Review of Progress in Clinical Photodynamic Therapy. Technol. Cancer Res. Treat. 2016, 4, 283-293. [CrossRef] [PubMed]

47. Yun, S.H.; Kwok, S.J.J. Light in diagnosis, therapy and surgery. Nat. Biomed. Eng. 2017, 1, 0008. [CrossRef] [PubMed]

48. Wang, L.; Yin, H.; Jabed, M.A.; Hetu, M.; Wang, C.; Monro, S.; Zhu, X.; Kilina, S.; McFarland, S.A.; Sun, W. $\pi$-Expansive Heteroleptic Ruthenium(II) Complexes as Reverse Saturable Absorbers and Photosensitizers for Photodynamic Therapy. Inorg. Chem. 2017, 56, 3245-3259. [CrossRef] [PubMed]

49. Abreu, F.D.; Paulo, T.F.; Gehlen, M.H.; Ando, R.A.; Lopes, L.G.F.; Gondim, A.C.S.; Vasconcelos, M.A.; Teixeira, E.H.; Sousa, E.H.S.; de Carvalho, I.M.M. Aryl-Substituted Ruthenium(II) Complexes: A Strategy for Enhanced Photocleavage and Efficient DNA Binding. Inorg. Chem. 2017, 56, 9084-9096. [CrossRef] [PubMed]

50. Armitage, J.C.; Weersink, R.A. Photodynamic therapy for periodontal disease. In Opto-Canada: SPIE Regional Meeting on Optoelectronics, Photonics, and Imaging; SPIE: Bellingham, WA, USA, 2017; p. 108. [CrossRef]

51. Spring, B.Q.; Rizvi, I.; Xu, N.; Hasan, T. The role of photodynamic therapy in overcoming cancer drug resistance. Photochem. Photobiol. Sci. 2015, 14, 1476-1491. [CrossRef] [PubMed]

52. Jiang, P.; Mizushima, N. Autophagy and human diseases. Cell Res. 2013, 24, 69-79. [CrossRef] [PubMed]

53. Martinez, J.; Cunha, L.D.; Park, S.; Yang, M.; Lu, Q.; Orchard, R.; Li, Q.-Z.; Yan, M.; Janke, L.; Guy, C.; et al. Noncanonical autophagy inhibits the autoinflammatory, lupus-like response to dying cells. Nature 2016, 533, 115-119. [CrossRef] [PubMed]

54. Dolmans, D.E.J.G.J.; Fukumura, D.; Jain, R.K. TIMELINE: Photodynamic therapy for cancer. Nat. Rev. Cancer 2003, 3, 380-387. [CrossRef] [PubMed]

55. Galluzzi, L.; Buqué, A.; Kepp, O.; Zitvogel, L.; Kroemer, G. Immunogenic cell death in cancer and infectious disease. Nat. Rev. Immunol. 2016, 17, 97-111. [CrossRef] [PubMed]

56. Wang, H.; Yang, X.; Shao, W.; Chen, S.; Xie, J.; Zhang, X.; Wang, J.; Xie, Y. Ultrathin Black Phosphorus Nanosheets for Efficient Singlet Oxygen Generation. J. Am. Chem. Soc. 2015, 137, 11376-11382. [CrossRef] [PubMed]

57. Bacellar, I.; Tsubone, T.; Pavani, C.; Baptista, M. Photodynamic Efficiency: From Molecular Photochemistry to Cell Death. Int. J. Mol. Sci. 2015, 16, 20523-20559. [CrossRef] [PubMed]

58. McMahon, K.M.; Foit, L.; Angeloni, N.L.; Giles, F.J.; Gordon, L.I.; Thaxton, C.S. Synthetic High-Density Lipoprotein-Like Nanoparticles as Cancer Therapy. Cancer Treat Res. 2015, 166, 129-150. [CrossRef] [PubMed]

59. Xodo, L.E.; Cogoi, S.; Rapozzi, V. Photosensitizers binding to nucleic acids as anticancer agents. Future Med. Chem. 2016, 8, 179-194. [CrossRef] [PubMed]

60. Castano, A.P.; Demidova, T.N.; Hamblin, M.R. Mechanisms in photodynamic therapy: Part threePhotosensitizer pharmacokinetics, biodistribution, tumor localization and modes of tumor destruction. Photodiagn. Photodyn. Ther. 2005, 2, 91-106. [CrossRef]

61. Zhang, J.; Jiang, C.; Figueiró Longo, J.P.; Azevedo, R.B.; Zhang, H.; Muehlmann, L.A. An updated overview on the development of new photosensitizers for anticancer photodynamic therapy. Acta Pharm. Sin. B 2018, 8, 137-146. [CrossRef] [PubMed]

62. Xie, H.; Svenmarker, P.; Axelsson, J.; Gräfe, S.; Kyriazi, M.; Bendsoe, N.; Andersson-Engels, S.; Svanberg, K. Pharmacokinetic and biodistribution study following systemic administration of Fospeg ${ }^{\circledR}$-A Pegylated liposomal mTHPC formulation in a murine model. J. Biophotonics 2015, 8, 142-152. [CrossRef] [PubMed]

63. Silva, F.R.O.; Nabeshima, C.T.; Bellini, M.H.; Schor, N.; Vieira, N.D.; Courrol, L.C. Study of ProtoPorphyrin IX Elimination by Body Excreta: A new Noninvasive Cancer Diagnostic Method? J. Fluoresc. 2012, 23, 131-135. [CrossRef] [PubMed]

64. Moroishi, T.; Hansen, C.G.; Guan, K.-L. The emerging roles of YAP and TAZ in cancer. Nat. Rev. Cancer 2015, 15, 73-79. [CrossRef] [PubMed]

65. Yang, Z.; Xie, J.; Zhu, J.; Kang, C.; Chiang, C.; Wang, X.; Wang, X.; Kuang, T.; Chen, F.; Chen, Z.; et al. Functional exosome-mimic for delivery of siRNA to cancer: In vitro and in vivo evaluation. J. Controll. Release 2016, 243, 160-171. [CrossRef] [PubMed]

66. Zuckerman, J.E.; Davis, M.E. Clinical experiences with systemically administered siRNA-based therapeutics in cancer. Nat. Rev. Drug Discov. 2015, 14, 843-856. [CrossRef] [PubMed] 
67. Wu, C.; Chen, Z.; Hu, Y.; Rao, Z.; Wu, W.; Yang, Z. Nanocrystals: The preparation, precise control, and application toward the pharmaceutics and foods industry. Curr. Pharm. Des. 2018. [CrossRef] [PubMed]

68. Jain, R.K.; Stylianopoulos, T. Delivering nanomedicine to solid tumors. Nat. Rev. Clin. Oncol. 2010, 7, 653-664. [CrossRef] [PubMed]

69. Agostinis, P.; Berg, K.; Cengel, K.A.; Foster, T.H.; Girotti, A.W.; Gollnick, S.O.; Hahn, S.M.; Hamblin, M.R.; Juzeniene, A.; Kessel, D.; et al. Photodynamic therapy of cancer: An update. CA Cancer J. Clin. 2011, 61, 250-281. [CrossRef] [PubMed]

70. Yakavets, I.; Yankovsky, I.; Millard, M.; Lamy, L.; Lassalle, H.-P.; Wiehe, A.; Zorin, V.; Bezdetnaya, L. The alteration of temoporfin distribution in multicellular tumor spheroids by $\beta$-cyclodextrins. Int. J. Pharm. 2017, 529, 568-575. [CrossRef] [PubMed]

71. Lammers, T.; Kiessling, F.; Hennink, W.E.; Storm, G. Drug targeting to tumors: Principles, pitfalls and (pre-) clinical progress. J. Controll. Release 2012, 161, 175-187. [CrossRef] [PubMed]

72. Kharkwal, G.B.; Sharma, S.K.; Huang, Y.-Y.; Dai, T.; Hamblin, M.R. Photodynamic therapy for infections: Clinical applications. Lasers Surg. Med. 2011, 43, 755-767. [CrossRef] [PubMed]

73. Ormond, A.; Freeman, H. Dye Sensitizers for Photodynamic Therapy. Materials 2013, 6, 817-840. [CrossRef] [PubMed]

74. Zhang, S.; Gao, H.; Bao, G. Physical Principles of Nanoparticle Cellular Endocytosis. ACS Nano 2015, 9, 8655-8671. [CrossRef] [PubMed]

75. Mehraban, N.; Freeman, H. Developments in PDT Sensitizers for Increased Selectivity and Singlet Oxygen Production. Materials 2015, 8, 4421-4456. [CrossRef] [PubMed]

76. Kessel, D.; Conley, M.; Vicente, M.G.H.; Reiners, J.J. Studies on the Subcellular Localization of the Porphycene CPO. Photochem. Photobiol. 2005, 81, 569-572. [CrossRef] [PubMed]

77. Marchal, S.; François, A.; Dumas, D.; Guillemin, F.; Bezdetnaya, L. Relationship between subcellular localisation of Foscan ${ }^{\circledR}$ and caspase activation in photosensitised MCF-7 cells. Br. J. Cancer 2007, 96, 944-951. [CrossRef] [PubMed]

78. Rui, L.-L.; Cao, H.-L.; Xue, Y.-D.; Liu, L.-C.; Xu, L.; Gao, Y.; Zhang, W.-A. Functional organic nanoparticles for photodynamic therapy. Chin. Chem. Lett. 2016, 27, 1412-1420. [CrossRef]

79. Zhou, A.; Wei, Y.; Chen, Q.; Xing, D. In Vivo Near-Infrared Photodynamic Therapy Based on Targeted Upconversion Nanoparticles. J. Biomed. Nanotechnol. 2015, 11, 2003-2010. [CrossRef] [PubMed]

80. DeBerardinis, R.J.; Thompson, C.B. Cellular Metabolism and Disease: What Do Metabolic Outliers Teach Us? Cell 2012, 148, 1132-1144. [CrossRef] [PubMed]

81. Huang, Z.; Hsu, Y.-C.; Li, L.-B.; Wang, L.-W.; Song, X.-D.; Yow, C.M.N.; Lei, X.; Musani, A.I.; Luo, R.-C.; Day, B.J. Photodynamic therapy of cancer-Challenges of multidrug resistance. J. Innov. Opt. Health Sci. 2015, 08, 1530002. [CrossRef]

82. Debele, T.; Peng, S.; Tsai, H.-C. Drug Carrier for Photodynamic Cancer Therapy. Int. J. Mol. Sci. 2015, 16, 22094-22136. [CrossRef] [PubMed]

83. He, C.; Liu, D.; Lin, W. Self-Assembled Core-Shell Nanoparticles for Combined Chemotherapy and Photodynamic Therapy of Resistant Head and Neck Cancers. ACS Nano 2015, 9, 991-1003. [CrossRef] [PubMed]

84. Oniszczuk, A.; Wojtunik-Kulesza, K.A.; Oniszczuk, T.; Kasprzak, K. The potential of photodynamic therapy (PDT)—Experimental investigations and clinical use. Biomed. Pharmacother. 2016, 83, 912-929. [CrossRef] [PubMed]

85. Chen, Z.; Chen, Z.; Zhang, A.; Hu, J.; Wang, X.; Yang, Z. Electrospun nanofibers for cancer diagnosis and therapy. Biomater. Sci. 2016, 4, 922-932. [CrossRef] [PubMed]

86. Zhou, C.; Yang, Z.; Teng, L. Nanomedicine based on nucleic acids: Pharmacokinetic and pharmacodynamic perspectives. Curr. Pharm. Biotechnol. 2014, 15, 829-838. [CrossRef] [PubMed]

87. Yang, Z.; Yu, B.; Zhu, J.; Huang, X.; Xie, J.; Xu, S.; Yang, X.; Wang, X.; Yung, B.C.; Lee, L.J.; et al. A microfluidic method to synthesize transferrin-lipid nanoparticles loaded with siRNA LOR-1284 for therapy of acute myeloid leukemia. Nanoscale 2014, 6, 9742-9751. [CrossRef] [PubMed]

88. Chen, Z.; Zhang, A.; Wang, X.; Zhu, J.; Fan, Y.; Yu, H.; Yang, Z. The Advances of Carbon Nanotubes in Cancer Diagnostics and Therapeutics. J. Nanomater. 2017, 2017, 3418932. [CrossRef] 
89. Lee, L.J.; Yang, Z.; Rahman, M.; Ma, J.; Kwak, K.J.; McElroy, J.; Shilo, K.; Goparaju, C.; Yu, L.; Rom, W.; et al. Extracellular mRNA Detected by Tethered Lipoplex Nanoparticle Biochip for Lung Adenocarcinoma Detection. Am. J. Respir. Crit. Care Med. 2016, 193, 1431-1433. [CrossRef] [PubMed]

90. Chen, Z.; Cong, M.; Hu, J.; Yang, Z.; Chen, Z. Preparation of Functionalized $\mathrm{TiO}_{2} \mathrm{Nanotube}$ Arrays and Their Applications. Sci. Adv. Mater. 2016, 8, 1231-1241. [CrossRef]

91. Sha, L.; Chen, Z.; Chen, Z.; Zhang, A.; Yang, Z. Polylactic Acid Based Nanocomposites: Promising Safe and Biodegradable Materials in Biomedical Field. Int. J. Polym. Sci. 2016, 2016, 68691541. [CrossRef]

92. Yang, Z.; Chang, L.; Chiang, C.L.; Lee, L.J. Micro-/nano-electroporation for active gene delivery. Curr. Pharm. Des. 2015, 21, 6081-6088. [CrossRef] [PubMed]

93. Yang, Z.; Chang, L.; Li, W.; Xie, J. Novel biomaterials and biotechnology for nanomedicine. Eur. J. Med. Res. 2015, 1, 1-2. [CrossRef]

94. Chouikrat, R.; Seve, A.; Vanderesse, R.; Benachour, H.; Barberi-Heyob, M.; Richeter, S.; Raehm, L.; Durand, J.O.; Verelst, M.; Frochot, C. Non Polymeric Nanoparticles for Photodynamic Therapy Applications: Recent Developments. Curr. Med. Chem. 2012, 19, 781-792. [CrossRef] [PubMed]

95. Sortino, S. Photoactivated nanomaterials for biomedical release applications. J. Mater. Chem. 2012, 22, 301-318. [CrossRef]

96. Xie, J.; Teng, L.; Yang, Z.; Zhou, C.; Liu, Y.; Yung, B.C.; Lee, R.J. A polyethylenimine-linoleic acid conjugate for antisense oligonucleotide delivery. BioMed Res. Int. 2013, 2013, 710502. [CrossRef] [PubMed]

97. Chen, Z.; Zhang, A.; Yang, Z.; Wang, X.; Chang, L.; Chen, Z.; James Lee, L. Application of DODMA and Derivatives in Cationic Nanocarriers for Gene Delivery. Curr. Org. Chem. 2016, 20, 1813-1819. [CrossRef]

98. Calixto, G.; Bernegossi, J.; de Freitas, L.; Fontana, C.; Chorilli, M. Nanotechnology-Based Drug Delivery Systems for Photodynamic Therapy of Cancer: A Review. Molecules 2016, 21, 342. [CrossRef] [PubMed]

99. Svenskaya, Y.; Parakhonskiy, B.; Haase, A.; Atkin, V.; Lukyanets, E.; Gorin, D.; Antolini, R. Anticancer drug delivery system based on calcium carbonate particles loaded with a photosensitizer. Biophys. Chem. 2013, 182, 11-15. [CrossRef] [PubMed]

100. Cheng, L.; Wang, C.; Feng, L.; Yang, K.; Liu, Z. Functional Nanomaterials for Phototherapies of Cancer. Chem. Rev. 2014, 114, 10869-10939. [CrossRef] [PubMed]

101. Colombeau, L.; Acherar, S.; Baros, F.; Arnoux, P.; Gazzali, A.M.; Zaghdoudi, K.; Toussaint, M.; Vanderesse, R.; Frochot, C. Inorganic Nanoparticles for Photodynamic Therapy. In Light-Responsive Nanostructured Systems for Applications in Nanomedicine; Springer: Cham, Switzerland, 2016; Volume 370, pp. 113-134. [CrossRef]

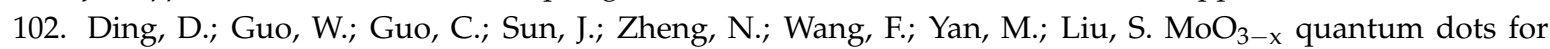
photoacoustic imaging guided photothermal/photodynamic cancer treatment. Nanoscale 2017, 9, 2020-2029. [CrossRef] [PubMed]

103. Alkilany, A.M.; Thompson, L.B.; Boulos, S.P.; Sisco, P.N.; Murphy, C.J. Gold nanorods: Their potential for photothermal therapeutics and drug delivery, tempered by the complexity of their biological interactions. Adv. Drug Deliv. Rev. 2012, 64, 190-199. [CrossRef] [PubMed]

104. Xie, J.; Lee, S.; Chen, X. Nanoparticle-based theranostic agents. Adv. Drug Deliv. Rev. 2010, 62, $1064-1079$. [CrossRef] [PubMed]

105. Pitsillides, C.M.; Joe, E.K.; Wei, X.; Anderson, R.R.; Lin, C.P. Selective Cell Targeting with Light-Absorbing Microparticles and Nanoparticles. Biophys. J. 2003, 84, 4023-4032. [CrossRef]

106. Hirsch, L.R.; Stafford, R.J.; Bankson, J.A.; Sershen, S.R.; Rivera, B.; Price, R.E.; Hazle, J.D.; Halas, N.J.; West, J.L. Nanoshell-mediated near-infrared thermal therapy of tumors under magnetic resonance guidance. Proc. Natl. Acad. Sci. USA 2003, 100, 13549-13554. [CrossRef] [PubMed]

107. Shan, G.; Weissleder, R.; Hilderbrand, S.A. Upconverting Organic Dye Doped Core-Shell Nano-Composites for Dual-Modality NIR Imaging and Photo-Thermal Therapy. Theranostics 2013, 3, 267-274. [CrossRef] [PubMed]

108. Zhang, Z.; Wang, J.; Chen, C. Gold Nanorods Based Platforms for Light-Mediated Theranostics. Theranostics 2013, 3, 223-238. [CrossRef] [PubMed]

109. Yang, X.; Yang, M.; Pang, B.; Vara, M.; Xia, Y. Gold Nanomaterials at Work in Biomedicine. Chem. Rev. 2015, 115, 10410-10488. [CrossRef] [PubMed]

110. Vankayala, R.; Lin, C.-C.; Kalluru, P.; Chiang, C.-S.; Hwang, K.C. Gold nanoshells-mediated bimodal photodynamic and photothermal cancer treatment using ultra-low doses of near infra-red light. Biomaterials 2014, 35, 5527-5538. [CrossRef] [PubMed] 
111. Kawasaki, H.; Kumar, S.; Li, G.; Zeng, C.; Kauffman, D.R.; Yoshimoto, J.; Iwasaki, Y.; Jin, R. Generation of Singlet Oxygen by Photoexcited Au25(SR)18 Clusters. Chem. Mater. 2014, 26, 2777-2788. [CrossRef]

112. Hone, D.C.; Walker, P.I.; Evans-Gowing, R.; FitzGerald, S.; Beeby, A.; Chambrier, I.; Cook, M.J.; Russell, D.A. Generation of Cytotoxic Singlet Oxygen via Phthalocyanine-Stabilized Gold Nanoparticles: A Potential Delivery Vehicle for Photodynamic Therapy. Langmuir 2002, 18, 2985-2987. [CrossRef]

113. Srivatsan, A.; Jenkins, S.V.; Jeon, M.; Wu, Z.; Kim, C.; Chen, J.; Pandey, R. Gold Nanocage-Photosensitizer Conjugates for Dual-Modal Image-Guided Enhanced Photodynamic Therapy. Theranostics 2014, 4, 163-174. [CrossRef] [PubMed]

114. Jennifer, M.; Connolly, V.R. Gold Nanosensitisers for Multimodal Optical Diagnostic Imaging and Therapy of Cancer. J. Nanomed. Nanotechnol. 2014, 5. [CrossRef]

115. Xiu, Z.-M.; Zhang, Q.-B.; Puppala, H.L.; Colvin, V.L.; Alvarez, P.J.J. Negligible Particle-Specific Antibacterial Activity of Silver Nanoparticles. Nano Lett. 2012, 12, 4271-4275. [CrossRef] [PubMed]

116. Khlebtsov, B.N.; Tuchina, E.S.; Khanadeev, V.A.; Panfilova, E.V.; Petrov, P.O.; Tuchin, V.V.; Khlebtsov, N.G. Enhanced photoinactivation ofStaphylococcus aureuswith nanocomposites containing plasmonic particles and hematoporphyrin. J. Biophotonics 2013, 6, 338-351. [CrossRef] [PubMed]

117. Sun, J.; Shen, J.; Chen, S.; Cooper, M.; Fu, H.; Wu, D.; Yang, Z. Nanofiller Reinforced Biodegradable PLA/PHA Composites: Current Status and Future Trends. Polymers 2018, 10, 505. [CrossRef]

118. Barbinta-Patrascu, M.E.; Bunghez, I.-R.; Iordache, S.M.; Badea, N.; Fierascu, R.-C.; Ion, R.M. Antioxidant Properties of Biohybrids Based on Liposomes and Sage Silver Nanoparticles. J. Nanosci. Nanotechnol. 2013, 13, 2051-2060. [CrossRef] [PubMed]

119. Kucková, L.; Jomová, K.; Švorcová, A.; Valko, M.; Segl’a, P.; Moncol', J.; Kožíšek, J. Synthesis, Crystal Structure, Spectroscopic Properties and Potential Biological Activities of Salicylate-Neocuproine Ternary Copper(II) Complexes. Molecules 2015, 20, 2115-2137. [CrossRef] [PubMed]

120. Wang, S.; Riedinger, A.; Li, H.; Fu, C.; Liu, H.; Li, L.; Liu, T.; Tan, L.; Barthel, M.J.; Pugliese, G.; et al. Plasmonic Copper Sulfide Nanocrystals Exhibiting Near-Infrared Photothermal and Photodynamic Therapeutic Effects. ACS Nano 2015, 9, 1788-1800. [CrossRef] [PubMed]

121. Li, Y.; Lu, W.; Huang, Q.; Li, C.; Chen, W. Copper sulfide nanoparticles for photothermal ablation of tumor cells. Nanomedicine 2010, 5, 1161-1171. [CrossRef] [PubMed]

122. Li, L.; Rashidi, L.H.; Yao, M.; Ma, L.; Chen, L.; Zhang, J.; Zhang, Y.; Chen, W. CuS nanoagents for photodynamic and photothermal therapies: Phenomena and possible mechanisms. Photodiagn. Photodyn. Ther. 2017, 19, 5-14. [CrossRef] [PubMed]

123. Hu, J.; Zhu, X.; Li, H.; Zhao, Z.; Chi, X.; Huang, G.; Huang, D.; Liu, G.; Wang, X.; Gao, J. Theranostic Au Cubic Nano-aggregates as Potential Photoacoustic Contrast and Photothermal Therapeutic Agents. Theranostics 2014, 4, 534-545. [CrossRef] [PubMed]

124. Krysko, D.V.; Garg, A.D.; Kaczmarek, A.; Krysko, O.; Agostinis, P.; Vandenabeele, P. Immunogenic cell death and DAMPs in cancer therapy. Nat. Rev. Cancer 2012, 12, 860-875. [CrossRef] [PubMed]

125. Paschos, A.; Pandya, R.; Duivenvoorden, W.C.M.; Pinthus, J.H. Oxidative stress in prostate cancer: Changing research concepts towards a novel paradigm for prevention and therapeutics. Prostate Cancer Prostatic Dis. 2013, 16, 217-225. [CrossRef] [PubMed]

126. Guo, L.; Yan, D.D.; Yang, D.; Li, Y.; Wang, X.; Zalewski, O.; Yan, B.; Lu, W. Combinatorial Photothermal and Immuno Cancer Therapy Using Chitosan-Coated Hollow Copper Sulfide Nanoparticles. ACS Nano 2014, 8, 5670-5681. [CrossRef] [PubMed]

127. Yan, L.; Amirshaghaghi, A.; Huang, D.; Miller, J.; Stein, J.M.; Busch, T.M.; Cheng, Z.; Tsourkas, A. Protoporphyrin IX (PpIX)-Coated Superparamagnetic Iron Oxide Nanoparticle (SPION) Nanoclusters for Magnetic Resonance Imaging and Photodynamic Therapy. Adv. Funct. Mater. 2018, 28, 1707030. [CrossRef] [PubMed]

128. Tietze, R.; Lyer, S.; Dürr, S.; Alexiou, C. Nanoparticles for cancer therapy using magnetic forces. Nanomedicine 2012, 7, 447-457. [CrossRef] [PubMed]

129. Espinosa, A.; Di Corato, R.; Kolosnjaj-Tabi, J.; Flaud, P.; Pellegrino, T.; Wilhelm, C. Duality of Iron Oxide Nanoparticles in Cancer Therapy: Amplification of Heating Efficiency by Magnetic Hyperthermia and Photothermal Bimodal Treatment. ACS Nano 2016, 10, 2436-2446. [CrossRef] [PubMed] 
130. Di Corato, R.; Béalle, G.; Kolosnjaj-Tabi, J.; Espinosa, A.; Clément, O.; Silva, A.K.A.; Ménager, C.; Wilhelm, C. Combining Magnetic Hyperthermia and Photodynamic Therapy for Tumor Ablation with Photoresponsive Magnetic Liposomes. ACS Nano 2015, 9, 2904-2916. [CrossRef] [PubMed]

131. Peng, J.; Qi, T.; Liao, J.; Chu, B.; Yang, Q.; Qu, Y.; Li, W.; Li, H.; Luo, F.; Qian, Z. Mesoporous Magnetic Gold "Nanoclusters" as Theranostic Carrier for Chemo-Photothermal Co-therapy of Breast Cancer. Theranostics 2014, 4, 678-692. [CrossRef] [PubMed]

132. Lu, K.; He, C.; Lin, W. Nanoscale Metal-Organic Framework for Highly Effective Photodynamic Therapy of Resistant Head and Neck Cancer. J. Am. Chem. Soc. 2014, 136, 16712-16715. [CrossRef] [PubMed]

133. Liu, J.; Yang, Y.; Zhu, W.; Yi, X.; Dong, Z.; Xu, X.; Chen, M.; Yang, K.; Lu, G.; Jiang, L.; et al. Nanoscale metal-organic frameworks for combined photodynamic \& radiation therapy in cancer treatment. Biomaterials 2016, 97, 1-9. [CrossRef] [PubMed]

134. Kang, C.; Sun, Y.; Zhu, J.; Li, W.; Zhang, A.; Kuang, T.; Xie, J.; Yang, Z. Delivery of Nanoparticles for Treatment of Brain Tumor. Curr. Drug MeTable 2016, 17, 745-754. [CrossRef]

135. Xie, J.; Yang, Z.; Zhou, C.; Zhu, J.; Lee, R.J.; Teng, L. Nanotechnology for the delivery of phytochemicals in cancer therapy. Biotechnol. Adv. 2016, 34, 343-353. [CrossRef] [PubMed]

136. Oberdörster, G.; Maynard, A.; Donaldson, K.; Castranova, V.; Fitzpatrick, J.; Ausman, K.; Carter, J.; Karn, B.; Kreyling, W.; Lai, D.; et al. Principles for characterizing the potential human health effects from exposure to nanomaterials: Elements of a screening strategy. Part. Fibre Toxicol. 2005, 2, 8. [CrossRef] [PubMed]

137. Zhou, Y.; Yokel, R.A. The Chemical Species of Aluminum Influences Its Paracellular Flux across and Uptake into Caco-2 Cells, a Model of Gastrointestinal Absorption. Toxicol. Sci. 2005, 87, 15-26. [CrossRef] [PubMed]

138. Warheit, D.B. Comparative Pulmonary Toxicity Assessment of Single-wall Carbon Nanotubes in Rats. Toxicol. Sci. 2003, 77, 117-125. [CrossRef] [PubMed]

139. Sharma, H.S.; Sharma, A. Nanoparticles aggravate heat stress induced cognitive deficits, blood-brain barrier disruption, edema formation and brain pathology. Prog. Brain Res. 2007, 162, 245-273. [CrossRef] [PubMed]

140. Chen, D.; Xi, T.; Bai, J. Biological effects induced by nanosilver particles: In vivo study. Biomed. Mat. 2007, 2, S126-S128. [CrossRef] [PubMed]

141. Kim, J.S.; Yoon, T.-J.; Yu, K.N.; Kim, B.G.; Park, S.J.; Kim, H.W.; Lee, K.H.; Park, S.B.; Lee, J.-K.; Cho, M.H. Toxicity and Tissue Distribution of Magnetic Nanoparticles in Mice. Toxicol. Sci. 2006, 89, 338-347. [CrossRef] [PubMed]

142. Li, C.; Taneda, S.; Taya, K.; Watanabe, G.; Li, X.; Fujitani, Y.; Nakajima, T.; Suzuki, A.K. Effects of in utero exposure to nanoparticle-rich diesel exhaust on testicular function in immature male rats. Toxicol. Lett. 2009, 185, 1-8. [CrossRef] [PubMed]

143. Das, J.; Choi, Y.-J.; Song, H.; Kim, J.-H. Potential toxicity of engineered nanoparticles in mammalian germ cells and developing embryos: Treatment strategies and anticipated applications of nanoparticles in gene delivery. Hum. Reprod. Update 2016, 22, 588-619. [CrossRef] [PubMed]

144. Pan, Y.; Neuss, S.; Leifert, A.; Fischler, M.; Wen, F.; Simon, U.; Schmid, G.; Brandau, W.; Jahnen-Dechent, W. Size-Dependent Cytotoxicity of Gold Nanoparticles. Small 2007, 3, 1941-1949. [CrossRef] [PubMed]

145. Wang, S.; Lu, W.; Tovmachenko, O.; Rai, U.S.; Yu, H.; Ray, P.C. Challenge in understanding size and shape dependent toxicity of gold nanomaterials in human skin keratinocytes. Chem. Phys. Lett. 2008, 463, 145-149. [CrossRef] [PubMed]

146. Li, J.J.; Zou, L.; Hartono, D.; Ong, C.N.; Bay, B.H.; Lanry Yung, L.Y. Gold Nanoparticles Induce Oxidative Damage in Lung Fibroblasts In Vitro. Adv. Mater. 2008, 20, 138-142. [CrossRef]

147. Shukla, R.; Bansal, V.; Chaudhary, M.; Basu, A.; Bhonde, R.R.; Sastry, M. Biocompatibility of Gold Nanoparticles and Their Endocytotic Fate Inside the Cellular Compartment: A Microscopic Overview. Langmuir 2005, 21, 10644-10654. [CrossRef] [PubMed]

148. Connor, E.E.; Mwamuka, J.; Gole, A.; Murphy, C.J.; Wyatt, M.D. Gold Nanoparticles Are Taken Up by Human Cells but Do Not Cause Acute Cytotoxicity. Small 2005, 1, 325-327. [CrossRef] [PubMed]

149. Carlson, C.; Hussain, S.M.; Schrand, A.M.; Braydich-Stolle, L.K.; Hess, K.L.; Jones, R.L.; Schlager, J.J. Unique Cellular Interaction of Silver Nanoparticles: Size-Dependent Generation of Reactive Oxygen Species. J. Phys. Chem. B 2008, 112, 13608-13619. [CrossRef] [PubMed]

150. Kim, Y.S.; Kim, J.S.; Cho, H.S.; Rha, D.S.; Kim, J.M.; Park, J.D.; Choi, B.S.; Lim, R.; Chang, H.K.; Chung, Y.H.; et al. Twenty-Eight-Day Oral Toxicity, Genotoxicity, and Gender-Related Tissue Distribution of Silver Nanoparticles in Sprague-Dawley Rats. Inhal. Toxicol. 2008, 20, 575-583. [CrossRef] [PubMed] 
151. Ji, J.H.; Jung, J.H.; Kim, S.S.; Yoon, J.-U.; Park, J.D.; Choi, B.S.; Chung, Y.H.; Kwon, I.H.; Jeong, J.; Han, B.S.; et al. Twenty-Eight-Day Inhalation Toxicity Study of Silver Nanoparticles in Sprague-Dawley Rats. Inhal. Toxicol. 2008, 19, 857-871. [CrossRef] [PubMed]

152. Rahman, M.F.; Wang, J.; Patterson, T.A.; Saini, U.T.; Robinson, B.L.; Newport, G.D.; Murdock, R.C.; Schlager, J.J.; Hussain, S.M.; Ali, S.F. Expression of genes related to oxidative stress in the mouse brain after exposure to silver-25 nanoparticles 2 . Toxicol. Lett. 2009, 187, 15-21. [CrossRef] [PubMed]

153. Chen, Z.; Meng, H.; Xing, G.; Chen, C.; Zhao, Y.; Jia, G.; Wang, T.; Yuan, H.; Ye, C.; Zhao, F.; et al. Acute toxicological effects of copper nanoparticles in vivo. Toxicol. Lett. 2006, 163, 109-120. [CrossRef] [PubMed]

154. Song, L.; Connolly, M.; Fernández-Cruz, M.L.; Vijver, M.G.; Fernández, M.; Conde, E.; de Snoo, G.R.; Peijnenburg, W.J.G.M.; Navas, J.M. Species-specific toxicity of copper nanoparticles among mammalian and piscine cell lines. Nanotoxicology 2013, 8, 383-393. [CrossRef] [PubMed]

155. Griffitt, R.J.; Weil, R.; Hyndman, K.A.; Denslow, N.D.; Powers, K.; Taylor, D.; Barber, D.S. Exposure to Copper Nanoparticles Causes Gill Injury and Acute Lethality in Zebrafish (Danio rerio). Environ. Sci. Technol. 2007, 41, 8178-8186. [CrossRef] [PubMed]

156. Li, F.; Lei, C.; Shen, Q.; Li, L.; Wang, M.; Guo, M.; Huang, Y.; Nie, Z.; Yao, S. Analysis of copper nanoparticles toxicity based on a stress-responsive bacterial biosensor array. Nanoscale 2013, 5, 653-662. [CrossRef] [PubMed]

157. Hillyer, J.F.; Albrecht, R.M. Gastrointestinal persorption and tissue distribution of differently sized colloidal gold nanoparticles. J. Pharm. Sci. 2001, 90, 1927-1936. [CrossRef] [PubMed]

158. Asharani, P.V.; Lian Wu, Y.; Gong, Z.; Valiyaveettil, S. Toxicity of silver nanoparticles in zebrafish models. Nanotechnology 2008, 19, 255102. [CrossRef] [PubMed]

159. Sharma, H.S. Hyperthermia induced brain oedema: Current status \& future perspectives. Indian J. Med. Res. 2006, 123, 629-652. [PubMed]

160. Hussain, S.M.; Javorina, A.K.; Schrand, A.M.; Duhart, H.M.; Ali, S.F.; Schlager, J.J. The Interaction of Manganese Nanoparticles with PC-12 Cells Induces Dopamine Depletion. Toxicol. Sci. 2006, 92, 456-463. [CrossRef] [PubMed]

161. Soto, K.F.; Carrasco, A.; Powell, T.G.; Murr, L.E.; Garza, K.M. Biological effects of nanoparticulate materials. Mater. Sci. Eng. C 2006, 26, 1421-1427. [CrossRef]

162. Wang, J.; Zhou, G.; Chen, C.; Yu, H.; Wang, T.; Ma, Y.; Jia, G.; Gao, Y.; Li, B.; Sun, J. Acute toxicity and biodistribution of different sized titanium dioxide particles in mice after oral administration. Toxicol. Lett. 2007, 168, 176-185. [CrossRef] [PubMed]

163. Wang, J.; Rahman, M.F.; Duhart, H.M.; Newport, G.D.; Patterson, T.A.; Murdock, R.C.; Hussain, S.M.; Schlager, J.J.; Ali, S.F. Expression changes of dopaminergic system-related genes in PC12 cells induced by manganese, silver, or copper nanoparticles. NeuroToxicology 2009, 30, 926-933. [CrossRef] [PubMed]

164. Wagner, A.J.; Bleckmann, C.A.; Murdock, R.C.; Schrand, A.M.; Schlager, J.J.; Hussain, S.M. Cellular Interaction of Different Forms of Aluminum Nanoparticles in Rat Alveolar Macrophages. J. Phys. Chem. B 2007, 111, 7353-7359. [CrossRef] [PubMed]

(c) 2018 by the authors. Licensee MDPI, Basel, Switzerland. This article is an open access article distributed under the terms and conditions of the Creative Commons Attribution (CC BY) license (http://creativecommons.org/licenses/by/4.0/). 